\title{
OPEN A reusable mesoporous adsorbent for efficient treatment of hazardous triphenylmethane dye wastewater: RSM-CCD optimization and rapid microwave-assisted regeneration
}

\begin{abstract}
Payam Arabkhani ${ }^{1}$, Hamedreza Javadian ${ }^{2}$, Arash Asfaram ${ }^{3 凶}$ \& Seyed Nabiollah Hosseini ${ }^{1}$
In this research, mesoporous calcium aluminate nanostructures (meso- $\mathrm{CaAl}_{2} \mathrm{O}_{4}$ ) were synthesized using a citric acid-assisted sol-gel auto-combustion process as the potential adsorbent to eliminate toxic triphenylmethane dye malachite green (MG) from synthetic/real effluent. The surface morphology of meso- $\mathrm{CaAl}_{2} \mathrm{O}_{4}$ was highly porous with nanometric size and non-homogeneous surface. The specific surface area, total pore volume, and $\mathrm{BJH}$ pore diameter of meso- $\mathrm{CaAl}_{2} \mathrm{O}_{4}$ were $148.5 \mathrm{~m}^{2} \mathrm{~g}^{-1}, 1.39 \mathrm{~cm}^{3} \mathrm{~g}^{-1}$, and $19 \mathrm{~nm}$, respectively. The meso- $\mathrm{CaAl}_{2} \mathrm{O}_{4}$ also showed a very high heat resistance, due to losing only $7.95 \%$ of its weight up to $800^{\circ} \mathrm{C}$, which is mainly related to the moisture loss. The optimal adsorption conditions were obtained based on response surface methods (RSM)central composite design (CCD) techniques. The Langmuir isotherm model was used for fitting the adsorption measurements, which presented $587.5 \mathrm{mg} \mathrm{g}^{-1}$ as the maximum adsorption capacity of the dye. The data obtained from the adsorption kinetics model were found to correspond to the pseudosecond-order model. Also, the thermodynamic parameters including enthalpy change $\left(\Delta \mathrm{H}^{\circ}\right)$, entropy change $\left(\Delta S^{\circ}\right)$, and Gibbs free energy change $\left(\Delta G^{\circ}\right)$ indicated that $M G$ dye adsorption by the meso$\mathrm{CaAl}_{2} \mathrm{O}_{4}$ was feasible, endothermic, and occurred spontaneously. Furthermore, the meso- $\mathrm{CaAl}_{2} \mathrm{O}_{4}$ was regenerated by microwave irradiation under $900 \mathrm{~W}$ at $6 \mathrm{~min}$, and the MG dye removal efficiency was remained over $90 \%$ after the five cycles of microwave regeneration.
\end{abstract}

Water contamination is one of the most serious problems facing the world today. Among various pollotions such as pesticides, pharmaceutical materials, heavy metals, microplastics, and so on, dyes are highly radioactive, non-biodegradable and carcinogenic ${ }^{1}$. Dyes are abundant in the effluents of many manufacturing industries, including food, plastics, cosmetics, and textiles ${ }^{2}$. Consequently, it is critical to eliminate dyes from manufacturing effluents before releasing them into the environment. The textile industry ranks first in dye usage, and textile wastewater treatment is challenging ${ }^{3,4}$. As a triphenylmethane cationic dye, malachite green (MG, Fig. 1) is one of the most widely used synthetic colorants applied to dye silk, leather, cotton, and wool in textile industries ${ }^{5}$. MG dye is also used in the aquaculture industry due to its high effectiveness as an antibacterial, antifungal, and antiparasitic agent. Although MG dye in food fish production has been banned in many countries, due to its low cost and high efficacy is still used ${ }^{6}$. However, the consumption of MG dye contaminated water is dangerous and carcinogenic due to the presence of nitrogen in its structure and causes severe damage to humans and animals ${ }^{7}$. Therefore, the effective removal of MG dye residue in water and wastewater is still a serious environmental challenge. Various treatments methods such as physicochemical, biochemical, and electrochemical processes have been utilized to remove MG dye from textile wastewater ${ }^{8}$. On the other hand, the resistance of MG dye to light and oxidizing agents causes that biological and chemical deposition to have difficulty for its removal from wastewaters. Adsorption has been considered as an efficient method in terms of its low cost, ease of operation, simplicity, flexibility, insensitivity to toxic contaminants and has shown to be a successful alternative to traditional treatment approaches ${ }^{9}$. In recent years, various adsorbents have been empirically studied for their capacity for

\footnotetext{
${ }^{1}$ Department of Chemistry, Tehran North Branch, Islamic Azad University, Tehran, Iran. ${ }^{2}$ Chemistry \& Chemical Engineering Research Center of Iran (CCERCI), P.O. Box 14335-186, Tehran, Iran. ${ }^{3}$ Medicinal Plants Research Center, Yasuj University of Medical Sciences, Yasuj, Iran. ${ }^{\circledR}$ email: arash.asfaram@yums.ac.ir
} 


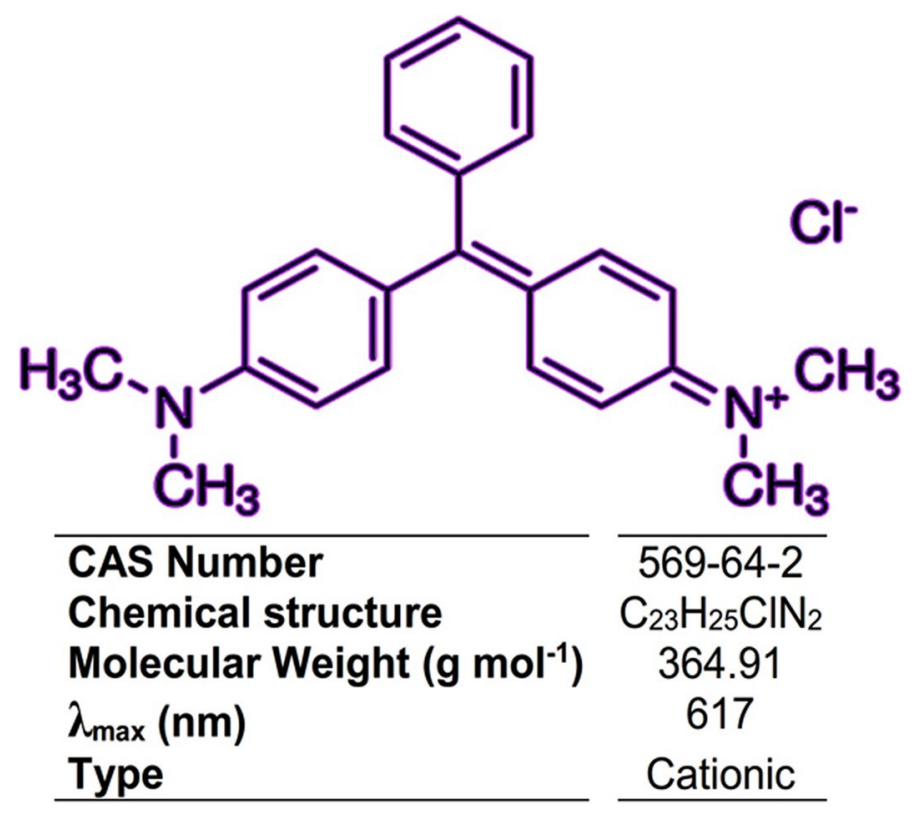

Figure 1. Chemical structure of MG dye.

the adsorption of MG dye, such as nanoparticles ${ }^{10}$, nano-sheets ${ }^{11}$, nanocomposites ${ }^{12}$, polymer aerogels ${ }^{13}$, carbonbased materials ${ }^{14}$, and metal-organic frameworks (ZIF-67) ${ }^{15}$.

To date, a variety of applications of calcium aluminate-containing materials have been reported, including catalyst $^{16}$, electrides and ionic conductor ${ }^{17}$, superhydrophobic cement ${ }^{18}$, biomaterial for dentistry and orthopedic fields ${ }^{19}$, bone cement ${ }^{20}$, hard tissue repair ${ }^{21}$, nanocatalyst for biodiesel production ${ }^{22}$, and adsorbent to remove aqueous $\mathrm{Cr}(\mathrm{VI})^{23}$. However, a review of the literature reveals that there are no records of monocalcium aluminate $\left(\mathrm{CaAl}_{2} \mathrm{O}_{4}\right)$ being used to remove $\mathrm{MG}$ dye from aqueous media. As a result, the current research presents the first confirmation of using $\mathrm{CaAl}_{2} \mathrm{O}_{4}$ for MG dye adsorption from contaminated water. To obtain $\mathrm{CaAl}_{2} \mathrm{O}_{4}$, several synthesis methods, such as solid-state reactions ${ }^{24}$, sol-gel ${ }^{25}$, Pechini method ${ }^{26}$, and solution combustion method ${ }^{27}$ have been introduced. Sol-gel auto-combustion is an innovative approach that integrates the solution-combustion synthesis and sol-gel processes and is based on the gelling and resulting combustion of an aqueous solution consisting of an organic fuel such as citric acid and metal salts ${ }^{28}$. This method benefits from using low-cost precursors, simple equipment, low processing cost, high production rate, low temperature, and ultrafine particles. In this study, we describe the synthesis of meso-CaAl ${ }_{2} \mathrm{O}_{4}$ nanostructure using the sol-gel auto-combustion method by citric acid as a fuel.

On the other hand, different factors including the adsorbent dose, primary concentration, solution $\mathrm{pH}$, temperature, and contact time have been shown to influence the efficiency of the adsorbent simultaneously ${ }^{29}$. As a result, optimizing the process requires a thorough understanding of how these factors interact simultaneously to impact adsorption. Thus, the experimental design as a collection of useful mathematical techniques was applied to improve the design and optimize the key parameters ${ }^{30}$. RSM (response surface methodology) is an effective statistical technique for simultaneously considering several independent variables and their interactions that impact the objective function. This strategy entails steadily reducing the number of trials and testing several regressions to find the conditions that yielded the best response for the methodological spectrum under consideration ${ }^{31}$. The central composite design (CCD) is a standard, effective, and most commonly used RSM design. In addition, in the adsorption technique, there is the serious challenge of the adsorbent regeneration with minimal efficiency loss. As a result, researchers have paid close attention to the use of several regeneration methods for reusing the adsorbent. Because of the unique molecular level heating capability of microwave-assisted regeneration technique, which leads to fast and homogeneous thermal reactions, it has recently been extensively investigated ${ }^{32}$.

In this study, for the first time, the citric acid-assisted sol-gel auto combustion was applied for the synthesis of meso- $\mathrm{CaAl}_{2} \mathrm{O}_{4}$ as adsorbent, and its structure was identified by using various state-of-the-art analytic technologies. Additionally, through utilizing CCD based on RSM, the influence of adsorption variables such as adsorbent dosage, solution $\mathrm{pH}$, contact time, initial dye concentration, and solution temperature was also assessed and optimized. The equilibrium adsorption isotherm models together with kinetic models and thermodynamic of the adsorption process for fitting the experimental data were also investigated. Finally, the reusability and performance of the adsorbent in real wastewater samples were studied.

\section{Experimental}

Chemicals and instruments. The chemicals and equipment used in this study were all specified in the "Electronic Supplementary Information." 


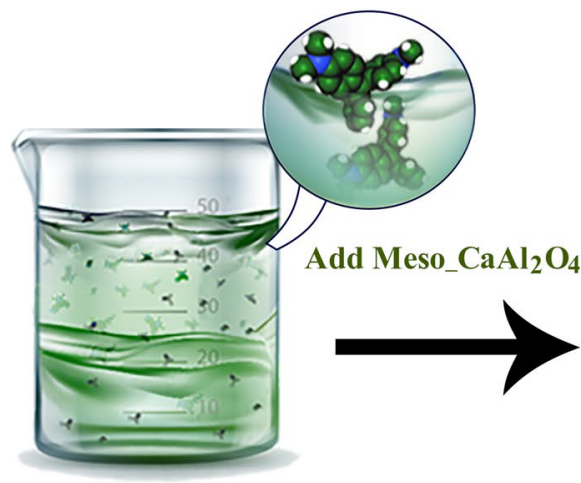

MG Dye Contaminated Solution

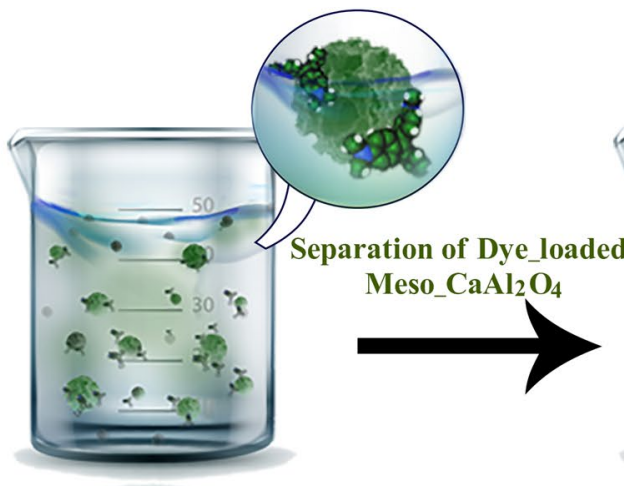

Dye Adsorption

$15 \min -25^{\circ} \mathrm{C}$

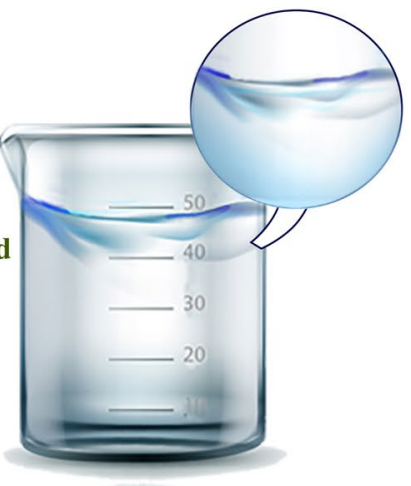

Purifed Solution
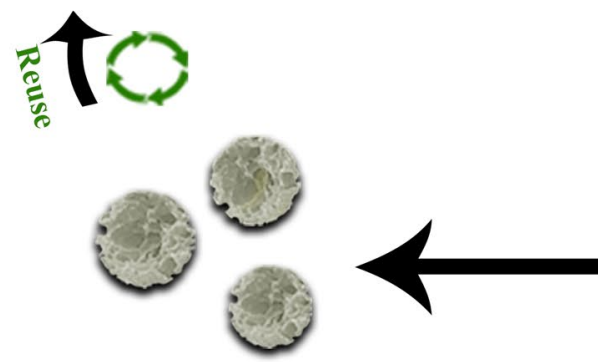

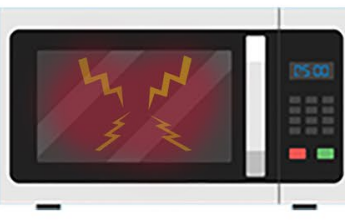

Microwave Heating $900 \mathrm{~W}-6 \mathrm{~min}$
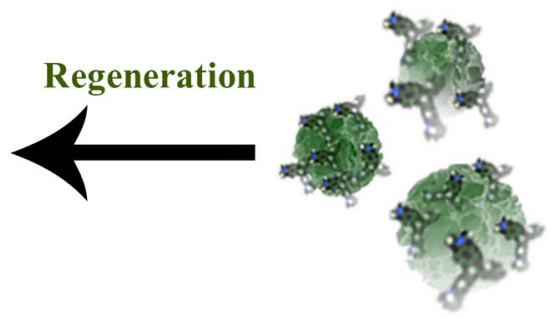

Saturated Meso_CaAl ${ }_{2} \mathrm{O}_{4}$

Regenerated Meso_CaAl ${ }_{2} \mathrm{O}_{4}$

Figure 2. The diagram of the MG dye adsorption by meso- $\mathrm{CaAl}_{2} \mathrm{O}_{4}$ and microwave-assisted regeneration.

Synthesis of meso- $\mathrm{CaAl}_{2} \mathrm{O}_{4}$. For the synthesis of meso- $\mathrm{CaAl}_{2} \mathrm{O}_{4}$, the citric acid-assisted sol-gel autocombustion technique was used as follows: suitable quantities of $\mathrm{Al}\left(\mathrm{NO}_{3}\right)_{3} \cdot 9 \mathrm{H}_{2} \mathrm{O}$ and $\mathrm{Ca}\left(\mathrm{NO}_{3}\right)_{3} \cdot 4 \mathrm{H}_{2} \mathrm{O}(2: 1)$ were dissolved in ultrapure water and kept stirring until a clear solution was obtained at room temperature. This solution was heated at $80^{\circ} \mathrm{C}$ for $15 \mathrm{~min}$, and citric acid was then dissolved into a minimal volume of water and added to the heated solution. The ratio of citric acid to nitrates was 1:1 (molar). The obtained reaction mixture was heated at a temperature of $80^{\circ} \mathrm{C}$, and adjusting $\mathrm{pH}$ to the value of 7 was carried out with the gradual addition of ammonium hydroxide solution $\left(0.1 \mathrm{~mol} \mathrm{~L}^{-1}\right)$. The mixture was gelled after $2 \mathrm{~h}$ of stirring. The gel was then heated for $1 \mathrm{~h}$ to obtain a yellowish-white mass in the oven at $200^{\circ} \mathrm{C}$ and then heated at $400{ }^{\circ} \mathrm{C}$ for 30 min until the auto-combustion process took place. Finally, the calcination of the powder was carried out at $700{ }^{\circ} \mathrm{C}$ for $1 \mathrm{~h}$ to obtain meso- $\mathrm{CaAl}_{2} \mathrm{O}_{4}$.

Adsorption procedure. By using a shaker (digital water bath incubator Drawell Scientific, Shanghai, China), equilibrium tests were performed by the following procedure: The shaker was loaded with $50 \mathrm{~mL}$ of triphenylmethane dye solutions containing meso- $\mathrm{CaAl}_{2} \mathrm{O}_{4}$ mass $(2-8 \mathrm{mg})$ and varying initial dye concentrations (20-100 $\left.\mathrm{m} \mathrm{L} \mathrm{L}^{-1}\right)$. Other experimental conditions were solution temperature of $5-45^{\circ} \mathrm{C}$, solution $\mathrm{pH}$ of $2.0-10$, and contact time of 5-25 min. After performing the experiments at predetermined time intervals, the adsorbent was separated, and then the remaining MG dye in the solutions was measured spectrophotometrically at $\lambda_{\max }$ of 617 nm (Fig. 2).

Central composite experimental design. CCD was performed to examine ${ }^{33,34}$ the effect of contact time, solution $\mathrm{pH}$, initial dye concentration, meso- $\mathrm{CaAl}_{2} \mathrm{O}_{4}$ mass, and solution temperature selected as the independent variables. As shown in Table 1 , each factor was examined in five levels $(-2,-1,0,+1$, and 2$)$ by performing 32 tests. The analysis of variance (ANOVA) statistical tests was accomplished to evaluate coefficients of determination $\left(\mathrm{R}^{2}\right)$, and F-test was also applied to define the significance of the effect of each variable. The optimum values of the variables were attained by applying the regression equation, investigating the counterresponse surface plot, and setting up constraints for the levels of the variables.

Regeneration of adsorbent. The regeneration of the dye-loaded meso- $\mathrm{CaAl}_{2} \mathrm{O}_{4}$ was carried out by microwave heating method using a $2.45 \mathrm{GHz}$ microwave oven with the maximum output power of $900 \mathrm{~W}$ in varying power levels and exposure times. After the MG dye adsorption process, the dye-loaded meso- $\mathrm{CaAl}_{2} \mathrm{O}_{4}$ was separated from the reaction medium and placed in the microwave oven in crucibles made of pure alumina and exposed to microwave heating. The bulk temperature of the meso- $\mathrm{CaAl}_{2} \mathrm{O}_{4}$ was measured by quickly inserting the thermocouple into the sample after ending the heating process with a digital display temperature controller. 


\begin{tabular}{|c|c|c|c|c|c|c|c|}
\hline \multicolumn{3}{|c|}{ Independent variables } & \multicolumn{5}{|c|}{ Range and levels (coded) } \\
\hline Factors & Coded & Units & $-\alpha$ & Low & Middle & High & $+\alpha$ \\
\hline $\mathrm{pH}$ & $\mathrm{X}_{1}$ & - & 2.0 & 4.0 & 6.0 & 8.0 & 10 \\
\hline MG concentration & $\mathrm{X}_{2}$ & $\mathrm{mg} \mathrm{L}^{-1}$ & 20 & 40 & 60 & 80 & 100 \\
\hline Adsorbent mass & $\mathrm{X}_{3}$ & $\mathrm{mg}$ & 2 & 3.5 & 5 & 6.5 & 8 \\
\hline Contact time & $\mathrm{X}_{4}$ & $\min$ & 5 & 10 & 15 & 20 & 25 \\
\hline Temperature & $\mathrm{X}_{5}$ & ${ }^{\circ} \mathrm{C}$ & 5 & 15 & 25 & 35 & 45 \\
\hline \multirow[b]{2}{*}{ Run order } & \multicolumn{5}{|c|}{ Adsorption variables } & Response & \\
\hline & $\mathrm{X}_{1}$ & $\mathrm{X}_{2}$ & $\mathbf{X}_{3}$ & $\mathrm{X}_{4}$ & $\mathbf{X}_{5}$ & R\% MG & \\
\hline 1 & 6.0 & 20.0 & 5.0 & 15 & 25 & 92.98 & \\
\hline 2 & 8.0 & 80.0 & 3.5 & 10 & 35 & 35.76 & \\
\hline 3 & 6.0 & 60.0 & 5.0 & 15 & 25 & 66.51 & \\
\hline 4 & 6.0 & 60.0 & 5.0 & 15 & 25 & 63.45 & \\
\hline 5 & 6.0 & 60.0 & 5.0 & 15 & 25 & 65.67 & \\
\hline 6 & 6.0 & 60.0 & 5.0 & 15 & 25 & 64.33 & \\
\hline 7 & 6.0 & 60.0 & 2.0 & 15 & 25 & 53.97 & \\
\hline 8 & 8.0 & 40.0 & 6.5 & 10 & 35 & 98.76 & \\
\hline 9 & 8.0 & 80.0 & 6.5 & 20 & 35 & 85.58 & \\
\hline 10 & \begin{tabular}{|l|}
8.0 \\
\end{tabular} & 40.0 & 3.5 & 20 & 35 & 97.45 & \\
\hline 11 & 4.0 & 80.0 & 6.5 & 10 & 35 & 57.68 & \\
\hline 12 & 8.0 & 40.0 & 3.5 & 10 & 15 & 68.97 & \\
\hline 13 & 6.0 & 60.0 & 5.0 & 15 & 25 & 62.65 & \\
\hline 14 & 6.0 & 60.0 & 5.0 & 15 & 45 & 75.88 & \\
\hline 15 & 4.0 & 40.0 & 6.5 & 20 & 35 & 75.56 & \\
\hline 16 & 6.0 & 60.0 & 5.0 & 5.0 & 25 & 48.93 & \\
\hline 17 & 4.0 & 40.0 & 3.5 & 10 & 35 & 59.87 & \\
\hline 18 & 6.0 & 60.0 & 8.0 & 15 & 25 & 91.57 & \\
\hline 19 & 4.0 & 80.0 & 3.5 & 20 & 35 & 54.34 & \\
\hline 20 & 6.0 & 60.0 & 5.0 & 25 & 25 & 92.56 & \\
\hline 21 & 6.0 & 100 & 5.0 & 15 & 25 & 40.87 & \\
\hline 22 & 4.0 & 40.0 & 3.5 & 20 & 15 & 69.87 & \\
\hline 23 & 4.0 & 40.0 & 6.5 & 10 & 15 & 68.78 & \\
\hline 24 & 4.0 & 80.0 & 6.5 & 20 & 15 & 70.75 & \\
\hline 25 & 8.0 & 80.0 & 3.5 & 20 & 15 & 65.78 & \\
\hline 26 & 8.0 & 80.0 & 6.5 & 10 & 15 & 49.87 & \\
\hline 27 & 2.0 & 60.0 & 5.0 & 15 & 25 & 40.65 & \\
\hline 28 & 6.0 & 60.0 & 5.0 & 15 & 25 & 65.11 & \\
\hline 29 & 8.0 & 40.0 & 6.5 & 20 & 15 & 96.21 & \\
\hline 30 & 6.0 & 60.0 & 5.0 & 15 & 5.0 & 54.33 & \\
\hline 31 & 10 & 60.0 & 5.0 & 15 & 25 & 77.78 & \\
\hline 32 & 4.0 & 80.0 & 3.5 & 10 & 15 & 8.86 & \\
\hline
\end{tabular}

Table 1. CCD experimental design matrix and responses for adsorption of MG dye by meso- $\mathrm{CaAl}_{2} \mathrm{O}_{4}$.

Finally, the regenerated meso- $\mathrm{CaAl}_{2} \mathrm{O}_{4}$ was washed with ultrapure water to remove the degraded MG dye on the meso- $\mathrm{CaAl}_{2} \mathrm{O}_{4}$ surface and was reused after drying in the oven (Fig. 2).

\section{Results and discussion}

Meso- $-\mathrm{CaAl}_{2} \mathrm{O}_{4}$ characterization. SEM images were used to analyze the surface morphology of meso$\mathrm{CaAl}_{2} \mathrm{O}_{4}$. Figure $3 \mathrm{a}$ shows the amorphous shape of meso- $\mathrm{CaAl}_{2} \mathrm{O}_{4}$ with a size of around $8 \mu \mathrm{m}$, which has a highly non-homogeneous surface with micrometric cavities. However, the magnified image shows that this porous structure is composed of aggregation and adhesion of near-spherical nanoparticles in the range between 10 and $20 \mathrm{~nm}$. In addition, a closer look reveals that the accumulation of these nanoparticles created cavities below $50 \mathrm{~nm}$ in the overall structure of sample, which led to the formation of the mesoporous structure (pore size ranging from 2 to $50 \mathrm{~nm}$ ). The formation of such a porosity in the sample results in obtaining a high value of the specific surface area in the sample. In the TEM image (Fig. 3b), this adhesion of nanoparticles of about $10 \mathrm{~nm}$ and the resulting holes is well visible, which is in line with SEM images. In Fig. 3c, the EDX spectrum shows the existence of $\mathrm{Ca}, \mathrm{Al}$, and $\mathrm{O}$ without any more peaks. It's also clear that there are no other elements in the synthesized adsorbent, and it was actually free of other impurities. 


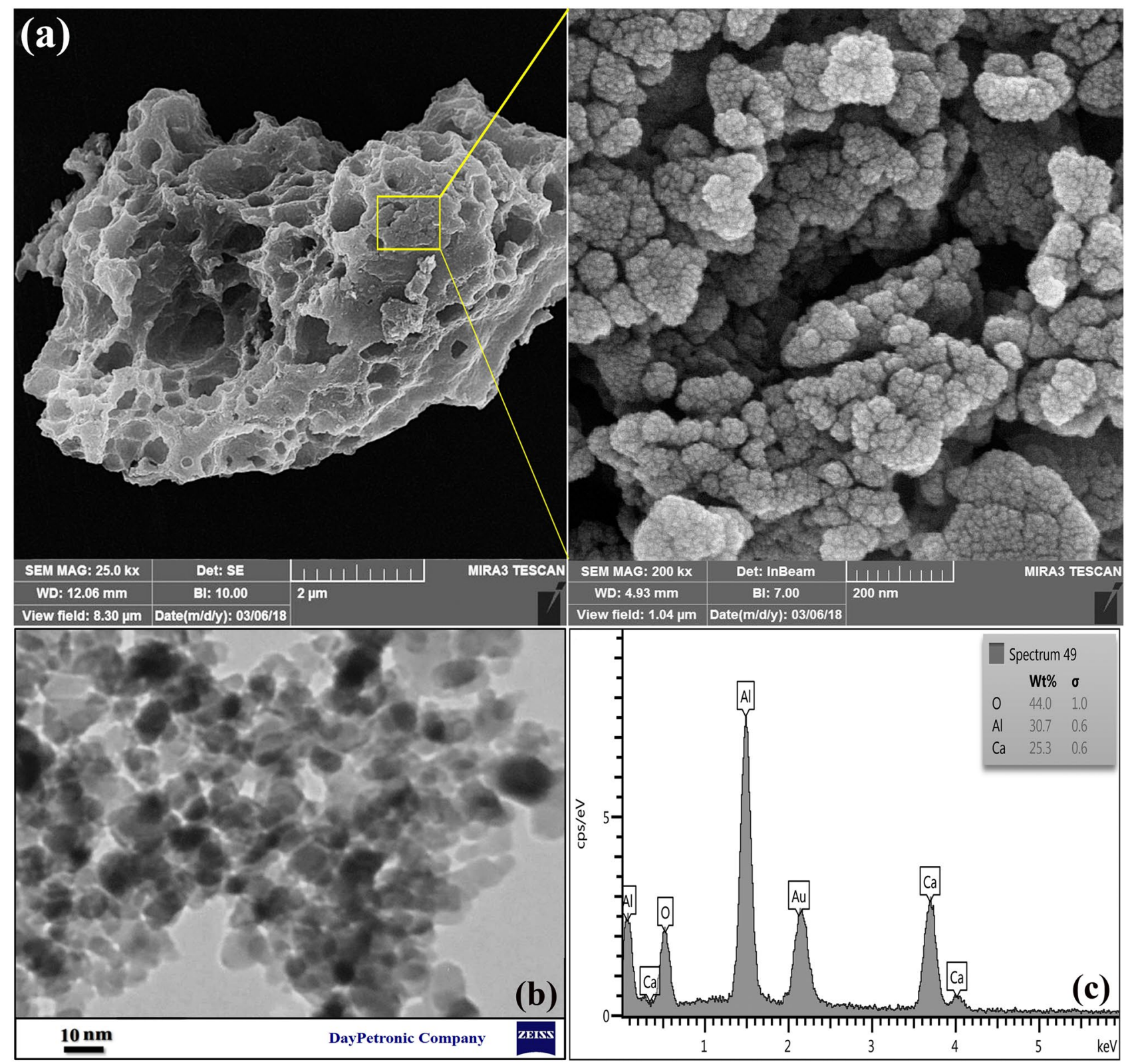

Figure 3. (a) SEM images, (b) TEM image, and (c) EDX analysis of meso- $\mathrm{CaAl}_{2} \mathrm{O}_{4}$.

The structure and phase purity of synthesized meso- $\mathrm{CaAl}_{2} \mathrm{O}_{4}$ was investigated by XRD and are shown in Fig. 4a. As can be seen, the successful synthesis of meso- $\mathrm{CaAl}_{2} \mathrm{O}_{4}$ can be proved according to JCPDS Card No. 00-001-0888, and no other impurities are found. The FT-IR spectrum was appliyed to determine the type of surface functional groups of meso- $\mathrm{CaAl}_{2} \mathrm{O}_{4}$ and is shown in Fig. $4 \mathrm{~b}$. The deformative vibration of the molecules of water is shown by stretching vibration of $\mathrm{OH}$ at $3437 \mathrm{~cm}^{-1}$ corresponding to free hydrogen-bonded hydroxyl groups ${ }^{30}$. The nitro groups of the precursors are responsible for other minor peaks shown at $1122 \mathrm{~cm}^{-1}$ and $1254 \mathrm{~cm}^{-135}$. The stretching vibration of the $\mathrm{M}-\mathrm{O}$ bond $(\mathrm{M}=\mathrm{Al}, \mathrm{Ca})$ is seen with the strong absorption band appeared at $823 \mathrm{~cm}^{-1}$. The stretching vibration of the $\mathrm{Ca}-\mathrm{O}$ bond is indicated at $617 \mathrm{~cm}^{-1}$ and $436 \mathrm{~cm}^{-1}$. The band at $528 \mathrm{~cm}^{-1}$ indicates the existence of aluminium ions confirming by the stretching vibration of $\mathrm{Al}-\mathrm{O}$. The bands at $1727 \mathrm{~cm}^{-1}$ and $2925 \mathrm{~cm}^{-1}$ are related to the existence of citrate ions that still present after calcination at $700{ }^{\circ} \mathrm{C}^{26}$. The surface area and pore structure properties of Meso- $\mathrm{CaAl}_{2} \mathrm{O}_{4}$ were evaluated using $\mathrm{N}_{2}$ adsorption/desorption isotherm, BET specific surface areas, and $\mathrm{BJH}$ pore size distribution analyses. According to the classification of IUPAC, the $\mathrm{N}_{2}$ adsorption/desorption isotherm of meso- $\mathrm{CaAl}_{2} \mathrm{O}_{4}$ (Fig. 4c) is a type $\mathrm{V}$ isotherm with a hysteresis loop of type $\mathrm{H} 1$, which is mostly associated with mesoporous structures. In addition, type $\mathrm{H} 1$ is often associated with porous materials, which consist of narrow pore-size distribution ${ }^{36}$. These findings mention the fact that meso- $\mathrm{CaAl}_{2} \mathrm{O}_{4}$ has a mesoporous structure, which is also seen in the SEM images. According to result of the BET, the adsorbent had $1.39 \mathrm{~cm}^{3} \mathrm{~g}^{-1}$ and $148.5 \mathrm{~m}^{2} \mathrm{~g}^{-1}$ of total pore volume and specific surface area, respectively. To further determine the pore size distribution of meso- $\mathrm{CaAl}_{2} \mathrm{O}_{4}$, the $\mathrm{BJH}$ equation was employed. According to IUPAC classification, pores $<2 \mathrm{~nm}$ are referred to as microporous, the pores ranging 

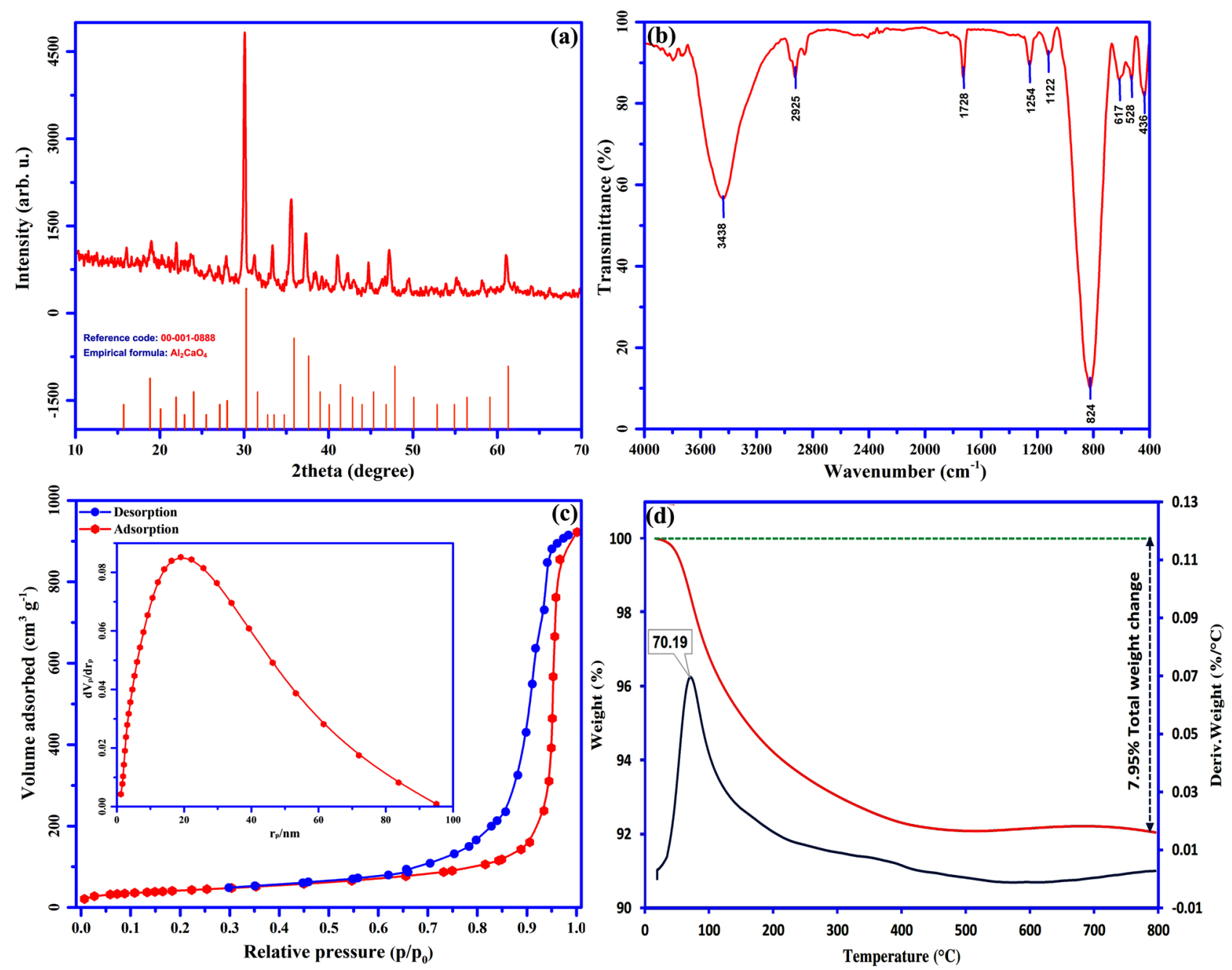

Figure 4. (a) X-ray diffraction, (b) FT-IR spectrum, (c) Nitrogen adsorption-desorption isotherm and BJH pore plot (inset), and (d) TG/DTG curves of meso- $\mathrm{CaAl}_{2} \mathrm{O}_{4}$.

from 2 to $50 \mathrm{~nm}$ are mesoporous, and the pores $>50 \mathrm{~nm}$ are called macroporous ${ }^{37}$. Figure $4 \mathrm{c}$ (inset) reveals that the distribution of pores size are between 10 to $40 \mathrm{~nm}$, proving the mesoporous structure of meso- $\mathrm{CaAl}_{2} \mathrm{O}_{4}$, and the majority of pores were around $19 \mathrm{~nm}$.

Figure $4 \mathrm{~d}$ shows the TGA-DTG curve of meso- $\mathrm{CaAl}_{2} \mathrm{O}_{4}$ heated from 25 to $800{ }^{\circ} \mathrm{C}$ in an air atmosphere (rate

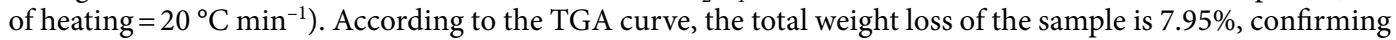
an excellent thermal resistance of meso- $\mathrm{CaAl}_{2} \mathrm{O}_{4}$. The major weight loss could be related to the loss of moisture in the sample, which takes place between 25 and $250^{\circ} \mathrm{C}$. After $400^{\circ} \mathrm{C}$ there is no noticeable weight loss, and sample weight is constant. The main rate of weight loss is also detected by the DTG analysis at $70.8^{\circ} \mathrm{C}$, which confirms the results obtained from the TGA analysis.

Data analysis. CCD model. For the quadratic model of MG dye adsorption, the coefficient of variation $(\mathrm{C} . \mathrm{V} \%)=2.544 \%$ and the F-value $=217.0$ (Probability $>\mathrm{F}$ less than 0.0001 ) attained by ANOVA (Table 2 ) imply that the model is highly significant, and the experimental results are reliable and accurate ${ }^{38}$. The P-value of lack of fit analysis acquired higher than $0.05(0.2861)$ is not significant for the quadratic model, which approving the reliability of the model for the prediction of the $\mathrm{MG}$ adsorption by meso- $\mathrm{CaAl}_{2} \mathrm{O}_{4}$. $\mathrm{MG}$ concentration $\left(\mathrm{X}_{2}\right)$, contact time $\left(\mathrm{X}_{4}\right)$, adsorbent mass $\left(\mathrm{X}_{3}\right), \mathrm{pH}\left(\mathrm{X}_{1}\right)$, temperature $\left(\mathrm{X}_{5}\right)$, the interaction effects of $\mathrm{X}_{2} \mathrm{X}_{4}, \mathrm{X}_{3} \mathrm{X}_{4}, \mathrm{X}_{2} \mathrm{X}_{3}, \mathrm{X}_{4} \mathrm{X}_{5}$, $\mathrm{X}_{1} \mathrm{X}_{2}$, and $\mathrm{X}_{1}^{2}$ and $\mathrm{X}_{4}^{2}$ are significant among all terms, due to the values of the $\mathrm{P}(<0.0001)$ (Fig. 5). The other coefficients are not significant $(\mathrm{P}>0.05)$.

Based on statistical results, a model for the prediction of the dye adsorption can be written as follows:

$$
\begin{aligned}
\mathrm{R} \%_{\mathrm{MG}}= & 30.0+12.55 \mathrm{X}_{1}-1.80 \mathrm{X}_{2}+0.82 \mathrm{X}_{3}+0.79 \mathrm{X}_{4}+1.04 \mathrm{X}_{5}-0.07 \mathrm{X}_{1} \mathrm{X}_{2}-0.36 \mathrm{X}_{1} \mathrm{X}_{3}+0.10 \mathrm{X}_{1} \mathrm{X}_{4} \\
& +0.12 \mathrm{X}_{2} \mathrm{X}_{3}+0.05 \mathrm{X}_{2} \mathrm{X}_{4}-0.51 \mathrm{X}_{3} \mathrm{X}_{4}-0.06 \mathrm{X}_{4} \mathrm{X}_{5}-0.38 \mathrm{X}_{1}^{2}+0.82 \mathrm{X}_{3}^{2}+0.05 \mathrm{X}_{4}^{2}
\end{aligned}
$$

The values of $\mathrm{R}^{2}=0.998$ and $\mathrm{Adj}-\mathrm{R}^{2}=0.993$ show that a good correlation between the results gathered by Eq. (1) and experimental data exists, indicating that the values are exact and reliable. In addition, the predicted 


\begin{tabular}{|c|c|c|c|c|c|c|}
\hline Source of variation & DF & SS & MS & F-value & P-value & Status \\
\hline Model & 12,340 & 20 & 617.2 & 217.0 & $<0.0001$ & Significant \\
\hline $\mathrm{X}_{1}$ & 1784 & 1 & 1784 & 627.3 & $<0.0001$ & Significant \\
\hline $\mathrm{X}_{2}$ & 4032 & 1 & 4032 & 1418 & $<0.0001$ & Significant \\
\hline $\mathrm{X}_{3}$ & 1971 & 1 & 1971 & 692.9 & $<0.0001$ & Significant \\
\hline $\mathrm{X}_{4}$ & 2693 & 1 & 2693 & 947.0 & $<0.0001$ & Significant \\
\hline $\mathrm{X}_{5}$ & 495.1 & 1 & 495.1 & 174.1 & $<0.0001$ & Significant \\
\hline $\mathrm{X}_{1} \mathrm{X}_{2}$ & 110.0 & 1 & 110.0 & 38.67 & $<0.0001$ & Significant \\
\hline $\mathrm{X}_{1} \mathrm{X}_{3}$ & 18.86 & 1 & 18.86 & 6.630 & 0.0258 & Significant \\
\hline $\mathrm{X}_{1} \mathrm{X}_{4}$ & 16.67 & 1 & 16.67 & 5.860 & 0.0340 & Significant \\
\hline $\mathrm{X}_{1} \mathrm{X}_{5}$ & 3.540 & 1 & 3.540 & 1.250 & 0.2881 & Not-significant \\
\hline $\mathrm{X}_{2} \mathrm{X}_{3}$ & 195.9 & 1 & 195.9 & 68.89 & $<0.0001$ & Significant \\
\hline $\mathrm{X}_{2} \mathrm{X}_{4}$ & 415.9 & 1 & 415.9 & 146.2 & $<0.0001$ & Significant \\
\hline $\mathrm{X}_{2} \mathrm{X}_{5}$ & 6.620 & 1 & 6.620 & 2.330 & 0.1554 & Not-significant \\
\hline $\mathrm{X}_{3} \mathrm{X}_{4}$ & 232.3 & 1 & 232.3 & 81.68 & $<0.0001$ & Significant \\
\hline $\mathrm{X}_{3} \mathrm{X}_{5}$ & 0.240 & 1 & 0.240 & 0.090 & 0.7757 & Not-significant \\
\hline $\mathrm{X}_{4} \mathrm{X}_{5}$ & 128.1 & 1 & 128.1 & 45.03 & $<0.0001$ & Significant \\
\hline $\mathrm{X}_{1}^{2}$ & 69.42 & 1 & 69.42 & 24.41 & 0.0004 & Significant \\
\hline $\mathrm{X}_{2}{ }^{2}$ & 4.440 & 1 & 4.440 & 1.560 & 0.2374 & Not-significant \\
\hline $\mathrm{X}_{3}^{2}$ & 100.4 & 1 & 100.4 & 35.31 & $<0.0001$ & Significant \\
\hline $\mathrm{X}_{4}{ }^{2}$ & 52.99 & 1 & 52.99 & 18.63 & 0.0012 & Significant \\
\hline $\mathrm{X}_{5}^{2}$ & 0.130 & 1 & 0.130 & 0.040 & 0.8362 & Not-significant \\
\hline Residual & 31.29 & 11 & 2.840 & & & \\
\hline Lack of Fit & 21.04 & 6 & 3.510 & 1.710 & 0.2861 & Not-significant \\
\hline Pure Error & 10.25 & 5 & 2.050 & & & \\
\hline Corr Total & 123,800 & 31 & & & & \\
\hline \multicolumn{7}{|c|}{ Model summary statistics } \\
\hline SD & CV\% & $\mathbf{R}^{2}$ & Adj- $\mathrm{R}^{2}$ & Predicted & Adequate precision & \\
\hline 1.687 & 2.544 & 0.9975 & 0.9929 & 0.9547 & 67.20 & \\
\hline
\end{tabular}

Table 2. ANOVA results for MG dye adsorption by meso-CaAl $\mathrm{O}_{4}$. DF Degree of freedom, $S S$ sum of squares, $M S$ mean of squares.

$\mathrm{R}^{2}$ values imply that the model has a significant block effect. The difference between the values of Adj- $\mathrm{R}^{2}(0.993)$ and predicted $R^{2}(0.955)$ should be roughly $0.20^{39}$ and their difference shows a problem along with either the model or data. An adequate precision value of 67.20 also confirms the validity of the model.

Poit of zero charge and and contour plots. The $\mathrm{pH}$ of a solution is known as a significant influencing factor that affects the adsorption performance. The point of zero charge ( $\mathrm{pHpzc}$ ) of meso-CaAl $\mathrm{O}_{4}$ was assessed by zeta potential analysis to find its surface charge at different $\mathrm{pH}$ values, and according to Fig. $6 \mathrm{a}$, the adsorbent is neutral, positively charged, and negatively charged at $\mathrm{pH}$ values $=8.7,>8.7,<8.7$, respectively.

For a better understanding of the effect of $\mathrm{pH}$, the results of the predicted models for $\mathrm{R} \% \mathrm{MG}$ as a function of $\mathrm{MG}$ concentration and $\mathrm{pH}$ of the solution is presented as a $2 \mathrm{D}$ contour plot (Fig. $6 \mathrm{~b}$ ). The corresponding figure shows the $\mathrm{R} \%$ of MG dye at different $\mathrm{pH}$ values. As can be seen, in an alkaline medium, the $\mathrm{R} \%$ is greater than in an acidic medium. By increasing $\mathrm{pH}$ from 2.0 to 10 , the $\mathrm{R} \%$ increases from 19.2 to $98.8 \%$, which can be due to an enhancement in electrostatic attraction between the molecules of MG dye and meso- $\mathrm{CaAl}_{2} \mathrm{O}_{4}$. As shown in Fig. 6b, when an increase in the initial concentration of MG is done from 20 to $100 \mathrm{mg} \mathrm{L}^{-1}$, the percentage of adsorbed dye decreases from 98.6 to $24.9 \%$. This may be due to the fact that higher dye concentration requires more active sites for dye adsorption. Therefore, more competition occurs between the molecules of MG dye and the binding sites of meso- $\mathrm{CaAl}_{2} \mathrm{O}_{4}$, and the $\mathrm{R} \%$ of $\mathrm{MG}$ decreases ${ }^{11}$. The photographic images of $\mathrm{MG}$ dye adsorption by meso- $\mathrm{CaAl}_{2} \mathrm{O}_{4}$ at different initial $\mathrm{pH}$ values are presented in Fig. $6 \mathrm{~b}$.

The simultaneous effect of the influencing parameters, including MG concentration, adsorbent mass, contact time, and temperature on the removal efficiency of MG dye by the adsorbent was assessed through a 2D contour plot and results are shown in Fig. 7.

Figure 7a shows the simultaneous effect of adsorbent mass and MG concentration on the percentage of MG dye adsorption. As can be seen, the highest $\mathrm{R} \%$ of $\mathrm{MG}$ occurred in the range of the simultaneous effect of lower dye concentration and higher adsorbent mass. The adsorption percentage of MG dye increases sharply from 19.6 to $98.2 \%$, with an enhancement in meso- $\mathrm{CaAl}_{2} \mathrm{O}_{4}$ mass. This may be attributed to the increased surface area and the existence of further adsorption sites. It is also a fact that increasing the adsorbent mass prevents the sites from saturating during the process ${ }^{30}$, 40 . Figure $7 \mathrm{~b}$ shows the simultaneous effect of adsorbent mass and contact time on the adsorption efficiency. The results showed that the removal efficiency increases with increasing time and 


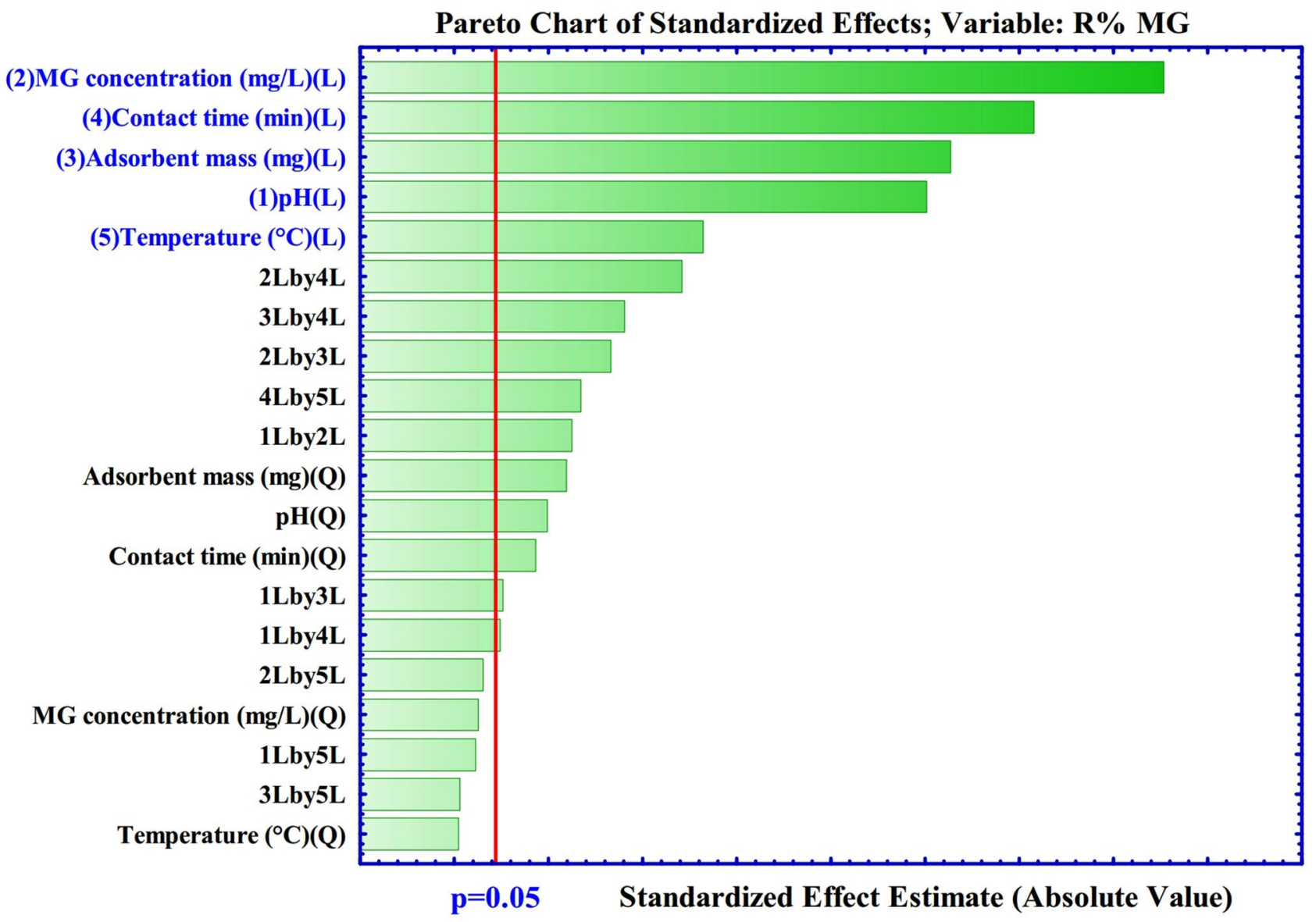

Figure 5. Pareto graph for the adsorption of MG dye.

adsorbent mass. The findings show that raising contact time from 5 to 25 min improves the R\% of MG from 46.7 to $98.7 \%$. The R \% reaches $89.6 \%$ in the first $15 \mathrm{~min}$ of contact time. The abundance of the empty sites available on the adsorbent surface can explain the rapid adsorption of the dye at the initial stage ${ }^{41}$.

The adsorption performance changes almost nothing after $15 \mathrm{~min}$, which could be due to the saturation of the sites of adsorption on the surface of meso- $\mathrm{CaAl}_{2} \mathrm{O}_{4}$ and the penetration of $\mathrm{MG}$ dye molecules into the pores ${ }^{31}$, 42. The simultaneous effect of MG concentration and contact time on the MG dye removal efficiency is shown in Fig. 7c. As shown, the highest MG dye removal efficiency was obtained at low MG concentrations and high contact times, which is related to the higher rate of active adsorption sites of the adsorbent compared to MG dye molecules at low MG concentrations. Also, increasing the contact time increases the access of dye molecules to the active adsorption sites of the adsorbent until the adsorbent reaches the saturation level. Figure $7 \mathrm{~d}$ shows the simultaneous effect of contact time and solution temperature on the MG dye removal efficiency. The results showed that with increasing contact time and temperature, the MG dye adsorption efficiency increased. Therefore, the efficacy of MG adsorption increases significantly from 34.8 to $98.2 \%$ as the temperature rises from 5 to $45^{\circ} \mathrm{C}$. However, up to $25^{\circ} \mathrm{C}, 96.0 \%$ of adsorption is achieved, and the impact of temperature on the adsorption performance is not significant $(95 \%$ to $98.2 \%)$ at temperatures beyond $25^{\circ} \mathrm{C}$.

Optimal conditions for $M G$ dye removal. The optimal value of the dependent variable (R\% $\mathrm{MG}$ ) was determined by the use of the function of desirability in STATISTICA software. The experimental conditions for maximum MG removal $(100 \%)$ are solution $\mathrm{pH}\left(\mathrm{X}_{1}\right)=8.0$, MG concentration $\left(\mathrm{X}_{2}\right)=50 \mathrm{mg} \mathrm{L}^{-1}$, meso-CaAl $\mathrm{O}_{4}$ mass $\left(\mathrm{X}_{3}\right)=8 \mathrm{mg}$, contact time $\left(\mathrm{X}_{4}\right)=15 \mathrm{~min}$, and solution temperature $\left(\mathrm{X}_{5}\right)=25^{\circ} \mathrm{C}$ (Fig. 8 ). The estimated values were used in an experimental test. The experimental $\mathrm{R} \%(98.68 \pm 2.11 \%)$ findings were nearly identical to the value predicted by the model, indicating that the model is highly reliable.

Adsorption isotherms modeling. The adsorption equilibrium isotherms are essential for conveying an adsorption process behavior. Four fitting models were used in this research as follows: Langmuir, Freundlich, Temkin, and Dubinin-Radushkevich (DR). Also, a dimensionless constant called separation factor $\left(R_{L}\right)$ was used to measure the nature of adsorption, in which $\mathrm{R}_{\mathrm{L}}>1$ indicates unfavorable adsorption, $\mathrm{R}_{\mathrm{L}}=0$ corresponds to irreversible adsorption, and $0<\mathrm{R}_{\mathrm{L}}<1$ relates to favorable adsorption ${ }^{43}$. Table 3 lists the fitting parameters for the adsorption isotherm models at different temperatures as well as the values of correlation coefficient $\left(R^{2}\right)$ values. According to the attained values of $\mathrm{R}^{2}$, the Langmuir model $\left(\mathrm{R}^{2}=0.999\right)$ was better fitts to other models at all temperatures, which indicates monolayer and homogeneous adsorption of MG dye molecules onto the surface 

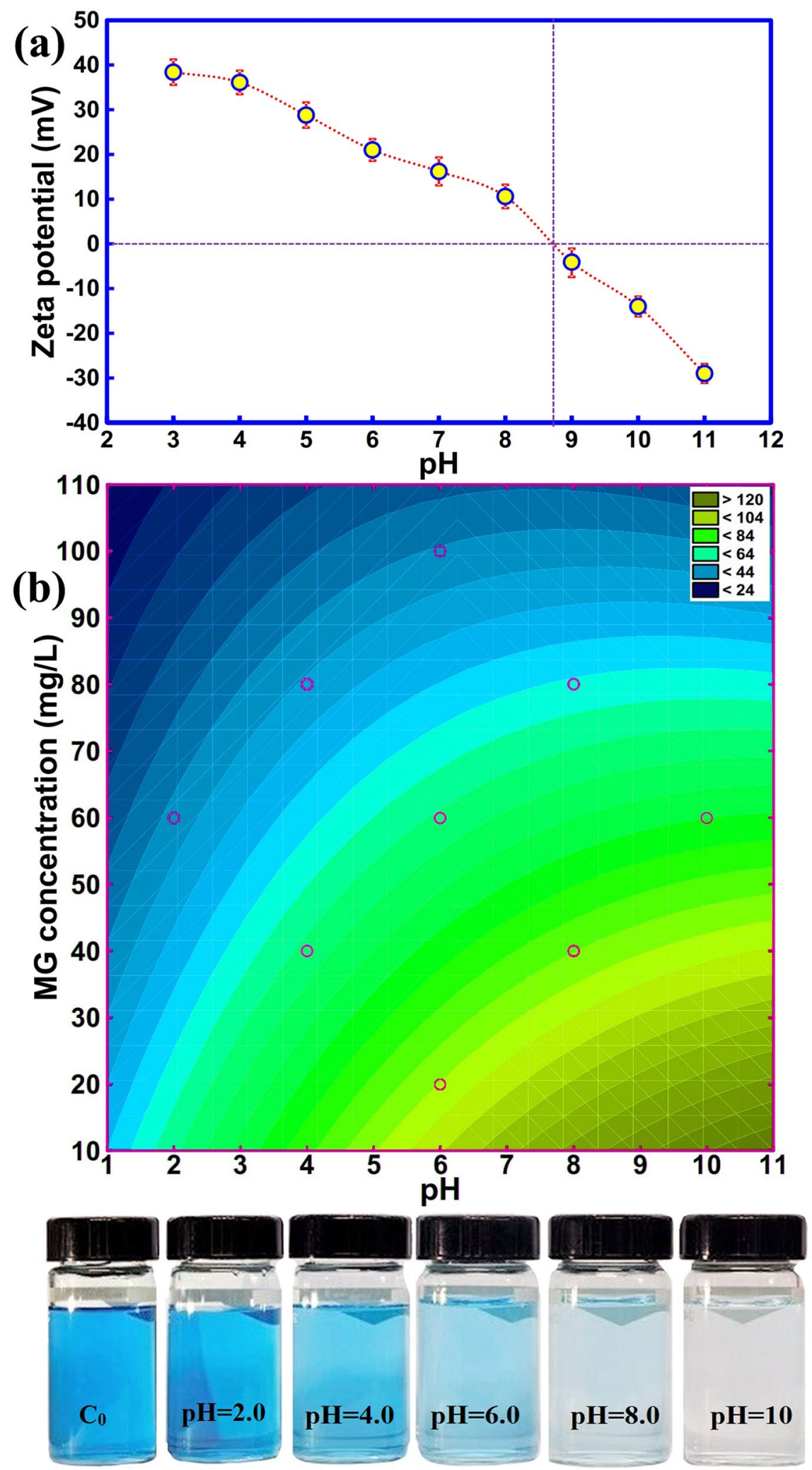

Figure 6. (a) Point of zero charge of meso- $\mathrm{CaAl}_{2} \mathrm{O}_{4}$ (error bars presents \pm standard deviations, $\mathrm{n}=3$ ), and (b) $2 \mathrm{D}$ plot showing the effect of $\mathrm{MG}$ concentration and solution $\mathrm{pH}$ on the $\mathrm{R} \%$ of $\mathrm{MG}$ dye. 

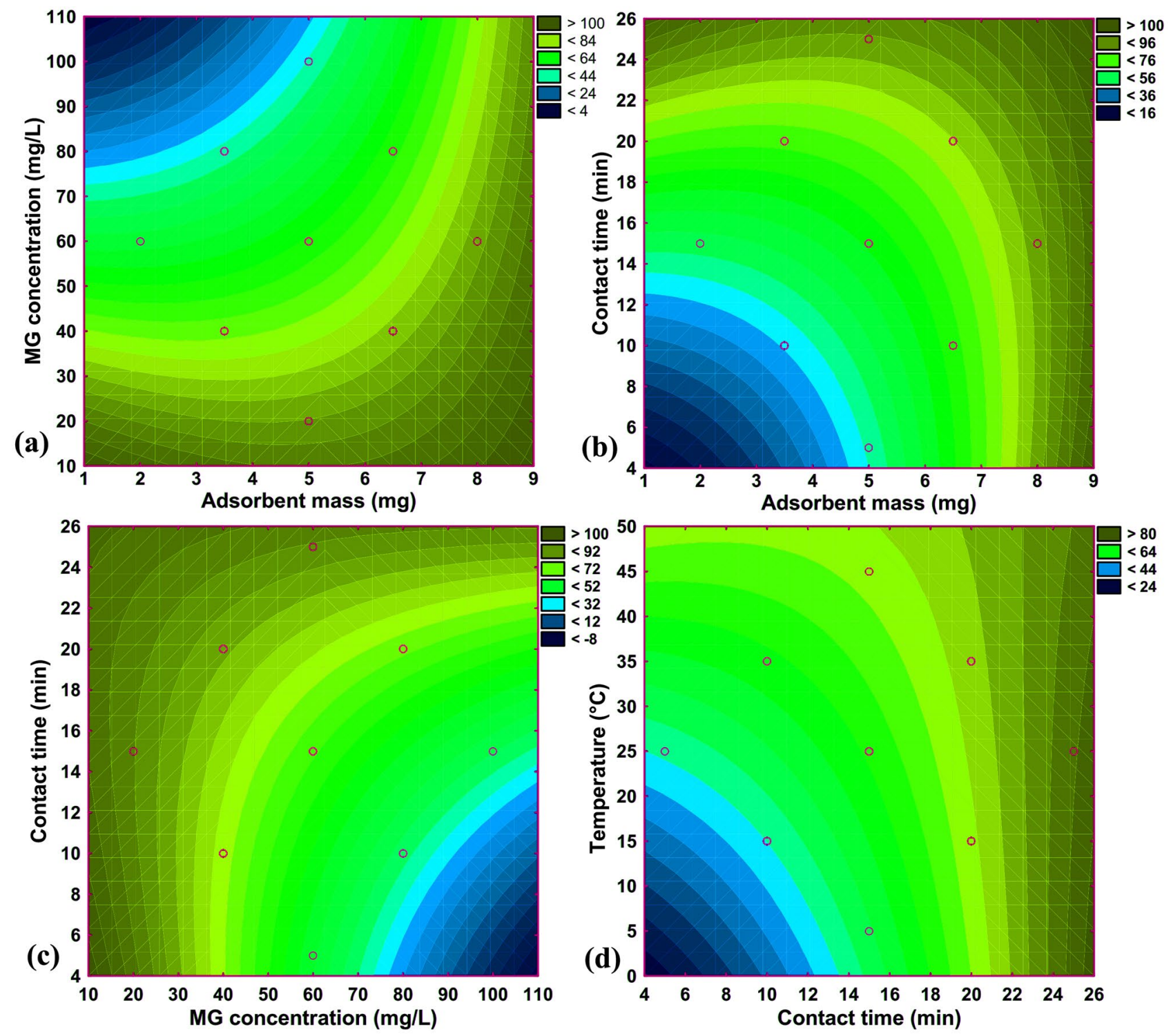

Figure 7. Contour plots showing the effects of (a) adsorbent mass-MG concentration, (b) adsorbent masscontact time, (c) MG concentration-contact time, and (d) contact time-temperature on the R \% of MG dye.

of meso- $\mathrm{CaAl}_{2} \mathrm{O}_{4}{ }^{44,45}$. It also reveals that the adsorbed molecules of MG dye onto meso- $\mathrm{CaAl}_{2} \mathrm{O}_{4}$ surfaces have no interaction ${ }^{46}$.

The results suggest that the Langmuir theoretical maximum monolayer adsorption capacity increases from 227.0 to $617.1 \mathrm{mg} \mathrm{g}^{-1}$ with an increase in temperature from 5 to $45^{\circ} \mathrm{C}$. However, the rate of increase in adsorption capacity is not significant with increasing temperature from 25 to $45^{\circ} \mathrm{C}$, and the maximum monolayer adsorption capacity of $587.5 \mathrm{mg} \mathrm{g}^{-1}$ obtained at $25^{\circ} \mathrm{C}$ is comparable to several other adsorbents applied in recent years to remove MG dye from aqueous medium (Table 4). Hence, the characteristics and performance of the investigated adsorbent, meso- $\mathrm{CaAl}_{2} \mathrm{O}_{4}$, support its appropriate as one potential adsorbent for removal of cationic pollutants such as MG from polluted aqueous systems. In addition, the $\mathrm{R}_{\mathrm{L}}$ values $\left(0<\mathrm{R}_{\mathrm{L}}<1\right)$, confirming favorable adsorption of MG dye onto meso- $\mathrm{CaAl}_{2} \mathrm{O}_{4}{ }^{47}$. In addition, The value of energy of adsorption (E) obtained from the D-R isotherm model (below $8 \mathrm{~kJ} \mathrm{~mol}^{-1}$ in all temperatures) suggests physical adsorption can be considered effective in the adsorption process ${ }^{12}$.

Adsorption kinetics modeling. The kinetics of MG dye adsorption by meso- $\mathrm{CaAl}{ }_{2} \mathrm{O}_{4}$ were investigated using pseudo-first-order, pseudo-second-order, intra-particle diffusion, and Elovich kinetic models under different solution $\mathrm{pH}$ conditions, and results are given in Table 5. As can be seen, the pseudo-second-order kinetic model fitted well for the whole range of solution $\mathrm{pH}$ conditions, showing the best correlation coefficient $\left(\mathrm{R}^{2}\right)$ values. This implies that the process of MG dye adsorption in a wide range of solution $\mathrm{pH}(2-10)$ mostly follows chemical adsorption ${ }^{70}$. It should be noted that the best $\left(\mathrm{R}^{2}\right)$ values are obtained at a solution $\mathrm{pH}$ of $8\left(\mathrm{R}^{2}=0.999\right)$, which indicates that the adsorption is more appropriate at this $\mathrm{pH}$. Furthermore, the qe value calculated from 
Profiles for Predicted Values and Desirability

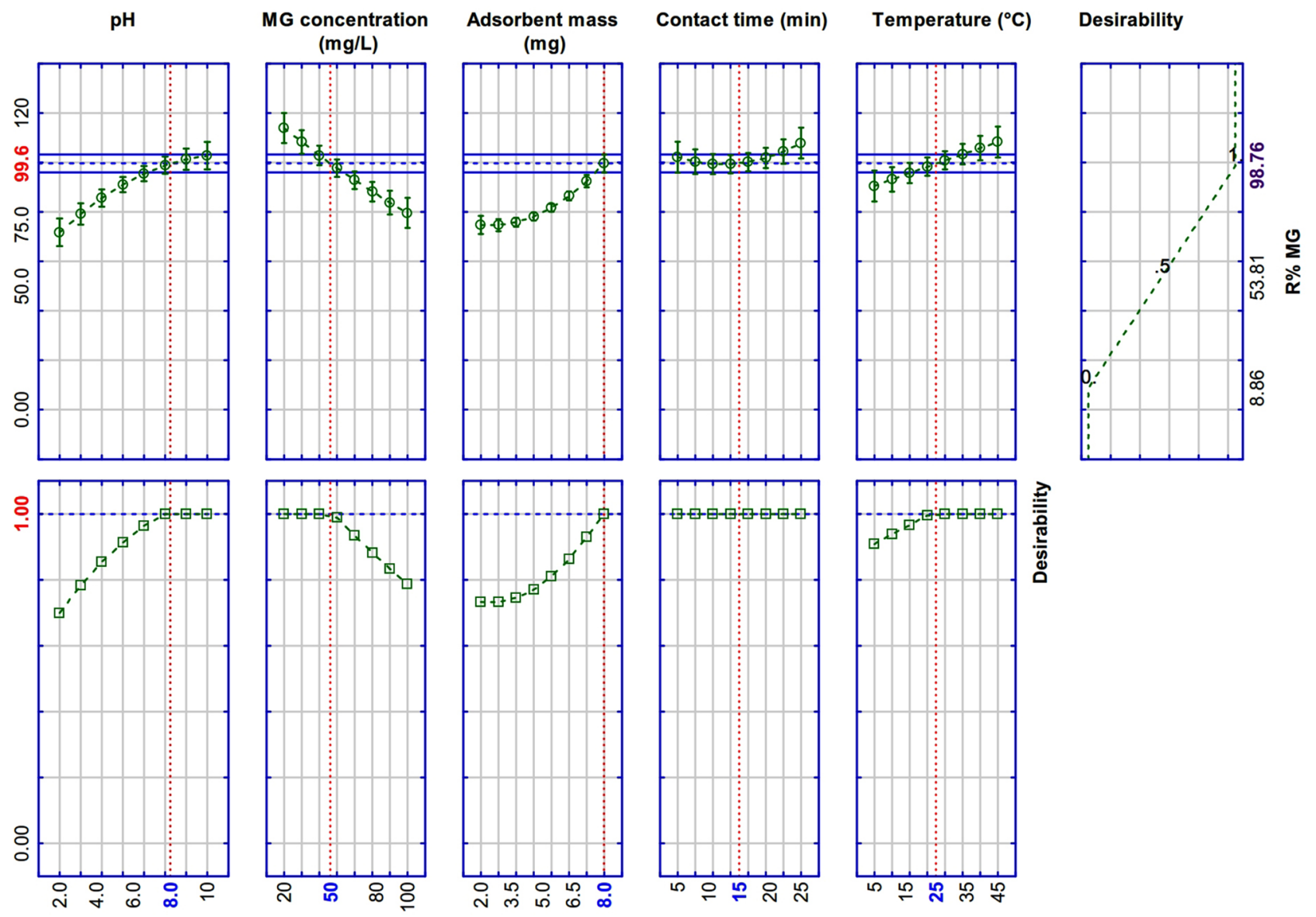

Figure 8. Optimal MG adsorption conditions from the model.

\begin{tabular}{|c|c|c|c|c|c|}
\hline \multirow[b]{2}{*}{ Isotherm } & \multirow[b]{2}{*}{ Plot } & \multirow{2}{*}{\begin{tabular}{|l|} 
Parameters \\
Temperature
\end{tabular}} & \multicolumn{3}{|l|}{ Values } \\
\hline & & & $5^{\circ} \mathrm{C}$ & $25^{\circ} \mathrm{C}$ & $45^{\circ} \mathrm{C}$ \\
\hline \multirow{4}{*}{$\frac{\text { Langmuir }}{\frac{C_{e}}{q_{e}}=\frac{1}{Q_{m} k_{L}}+\frac{C_{e}}{Q_{m}}}$} & \multirow{4}{*}{$C_{e} / q_{e}$ vs. $C_{e}$} & $\mathrm{Q}_{\mathrm{m}}\left(\mathrm{mg} \mathrm{g}^{-1}\right)$ & 227.0 & 587.5 & 617.1 \\
\hline & & $\mathrm{K}_{\mathrm{L}}\left(\mathrm{L} \mathrm{mg}^{-1}\right)$ & 0.247 & 0.235 & 0.293 \\
\hline & & \begin{tabular}{|l|}
$\mathrm{R}^{2}$ \\
\end{tabular} & 0.999 & 0.999 & 0.999 \\
\hline & & $\mathrm{R}_{\mathrm{L}}=1 /\left(1+\left(\mathrm{K}_{\mathrm{L}} \times \mathrm{C}_{0}\right)\right)$ & $0.039-0.288$ & $0.041-0.299$ & $0.033-0254$ \\
\hline \multirow{3}{*}{$\begin{array}{l}\text { Freundlich } \\
\ln q_{e}=\ln K_{F}+\frac{1}{n} \ln C_{e}\end{array}$} & \multirow{3}{*}{$\ln q_{e}$ vs. $\ln C_{e}$} & $1 / \mathrm{n}$ & 0.318 & 0.412 & 0.390 \\
\hline & & $\mathrm{K}_{\mathrm{F}}\left(\mathrm{L} \mathrm{mg}^{-1}\right)$ & 6.140 & 8.423 & 9.073 \\
\hline & & $\mathrm{R}^{2}$ & 0.932 & 0.933 & 0.932 \\
\hline \multirow{3}{*}{$\begin{array}{l}\text { Temkin } \\
q_{e}=B_{1} \ln K_{T}+B_{1} \ln C_{e}\end{array}$} & \multirow{3}{*}{$q_{e}$ vs. $\ln C_{e}$} & $\mathrm{~B}_{1}$ & 40.361 & 115.6 & 115.1 \\
\hline & & $\mathrm{K}_{\mathrm{T}}\left(\mathrm{L} \mathrm{mg}^{-1}\right)$ & 1.000 & 1.000 & 1.000 \\
\hline & & $\mathrm{R}^{2}$ & 0.972 & 0.985 & 0.988 \\
\hline \multirow{4}{*}{$\begin{array}{l}\text { Dubinin-Radushkevich (D-R) } \\
\ln q_{e}=\ln Q_{s}-k \varepsilon^{2}\end{array}$} & \multirow{4}{*}{$\ln q_{e}$ vs. $\varepsilon^{2}$} & $\mathrm{Q}_{\mathrm{S}}\left(\mathrm{mg} \mathrm{g}^{-1}\right)$ & 183.6 & 425.5 & 444.3 \\
\hline & & $\beta \times 10^{-7}$ & 4.189 & 3.473 & 2.129 \\
\hline & & $\mathrm{E}\left(\mathrm{kJ} \mathrm{mol}{ }^{-1}\right)$ & 1.092 & 1.200 & 1.533 \\
\hline & & $\mathrm{R}^{2}$ & 0.796 & 0.813 & 0.795 \\
\hline
\end{tabular}

Table 3. Isotherm model parameters for adsorption of $\mathrm{MG}$ dye onto meso- $\mathrm{CaAl}_{2} \mathrm{O}_{4}$ (volume $=50 \mathrm{~mL}$, adsorbent mass $=8 \mathrm{mg}$, contact time $=15 \mathrm{~min}$, and $\mathrm{pH} 8.0$ ). 


\begin{tabular}{|c|c|c|}
\hline Adsorbent & $Q_{\max }\left(\mathrm{mg} \mathrm{g}^{-1}\right)$ & Ref. \\
\hline Super paramagnetic sodium alginate-coated $\mathrm{Fe}_{3} \mathrm{O}_{4}-\mathrm{NPs}$ & 47.84 & 48 \\
\hline Graphene oxide/cellulose bead composites & 30.09 & 49 \\
\hline Montmorillonite clay & 262.5 & 50 \\
\hline Starch-graft-poly(acrylamide)/GO/hydroxyapatite nanocomposite & 297.0 & 51 \\
\hline $\mathrm{Fe}_{3} \mathrm{O}_{4} @ \mathrm{SiO}_{2}-\mathrm{GO}$ & 265.9 & 52 \\
\hline 3D magnetic bacterial cellulose nanofiber/GO polymer aerogel & 270.3 & 13 \\
\hline Hematite-reduced graphene oxide composites & 438.8 & 53 \\
\hline Nano-iron oxide-loaded alginate microspheres & 2.30 & 54 \\
\hline Tin oxide nanoparticle loaded on activated carbon & 142.9 & 55 \\
\hline Gold nanoparticles loaded on activated carbon & 164.6 & 56 \\
\hline NiS nanoparticles synthesized using plant leaf extract & 64.85 & 57 \\
\hline $\mathrm{TiO}_{2}$ Nanoparticles & 6.30 & 58 \\
\hline Activated carbon $/ \mathrm{CoFe}_{2} \mathrm{O}_{4}$ composite & 89.29 & 59 \\
\hline Graphene oxide and reduced graphene oxide & 13.52 & 60 \\
\hline Zeolite nanostructures & 226.8 & 61 \\
\hline Expanded graphite & 41.49 & 62 \\
\hline Reduced graphene oxide & 476.2 & 11 \\
\hline Mesoporous exfoliated graphite & 384.6 & 63 \\
\hline Amino functionalized graphenes & 91.48 & 64 \\
\hline Activated carbon derived from biomass & 48.48 & 65 \\
\hline Functionalized multi walled carbon nanotubes & 142.9 & 66 \\
\hline Bentonite & 178.6 & 67 \\
\hline Organo clay & 56.82 & 68 \\
\hline Natural zeolite & 36.50 & 69 \\
\hline Meso- $\mathrm{CaAl}_{2} \mathrm{O}_{4}$ & 587.5 & This work \\
\hline
\end{tabular}

Table 4. Comparison of meso- $\mathrm{CaAl}_{2} \mathrm{O}_{4}$ with other materials reported in the literature for MG dye adsorption (estimated by Langmuir isotherm).

\begin{tabular}{|c|c|c|c|c|c|c|c|}
\hline \multirow[b]{2}{*}{ Model } & \multirow[b]{2}{*}{ Plot } & \multirow{2}{*}{\begin{tabular}{|l|} 
Parameters \\
pH
\end{tabular}} & \multicolumn{5}{|l|}{ Values } \\
\hline & & & 2.0 & \begin{tabular}{|l|}
4.0 \\
\end{tabular} & 6.0 & \begin{tabular}{|l|}
8.0 \\
\end{tabular} & 10 \\
\hline \multirow{3}{*}{$\begin{array}{l}\text { First-order- kinetic } \\
\ln \left(q_{e}-q_{t}\right)=\ln q_{e}-k_{1} t\end{array}$} & \multirow{3}{*}{$\ln \left(q_{e}-q_{t}\right)$ vs. $t$} & $\mathrm{k}_{1}\left(\min ^{-1}\right)$ & 0.257 & 0.251 & 0.251 & 0.301 & 0.301 \\
\hline & & $\mathrm{q}_{\mathrm{e}(\mathrm{calc})}\left(\mathrm{mg} \mathrm{g}^{-1}\right)$ & 318.4 & 411.0 & 519.9 & 727.8 & 746.1 \\
\hline & & $\mathrm{R}^{2}$ & 0.770 & 0.719 & 0.715 & 0.944 & 0.920 \\
\hline \multirow{4}{*}{$\begin{array}{l}\text { Pseudo-second-order-kinetic } \\
\frac{t}{q_{t}}=\frac{1}{k_{2} q_{e}^{2}}+\frac{t}{q_{e}}\end{array}$} & \multirow{4}{*}{$t / q_{t}$ vs. $t$} & $\mathrm{k}_{2}\left(\min ^{-1}\right)$ & 0.0006 & 0.0003 & 0.0003 & 0.0002 & 0.0002 \\
\hline & & $\mathrm{q}_{\mathrm{e} \text { (calc) }}\left(\mathrm{mg} \mathrm{g}^{-1}\right)$ & 252.8 & 373.0 & 457.2 & 595.3 & 618.1 \\
\hline & & $\mathrm{R}^{2}$ & 0.992 & 0.996 & 0.992 & 0.999 & 0.992 \\
\hline & & $\mathrm{h}\left(\mathrm{mg} \mathrm{g}^{-1} \mathrm{~min}^{-1}\right)$ & 37.33 & 40.77 & 54.17 & \begin{tabular}{|l|}
73.4 \\
\end{tabular} & 70.36 \\
\hline \multirow{3}{*}{$\begin{array}{l}\text { Intraparticle diffusion } \\
q_{t}=k_{\text {diff }} t^{1 / 2}+C\end{array}$} & \multirow{3}{*}{$q_{t}$ vs. $t^{1 / 2}$} & $\mathrm{~K}_{\text {diff }}\left(\mathrm{mg} \mathrm{g}^{-1} \mathrm{~min}^{-1 / 2}\right)$ & 45.40 & 64.39 & 80.42 & 105.4 & 107.94 \\
\hline & & $\mathrm{C}\left(\mathrm{mg} \mathrm{g}^{-1}\right)$ & 0.75 & 16.85 & 17.76 & 18.66 & 25.72 \\
\hline & & $\mathrm{R}^{2}$ & 0.990 & 0.990 & 0.992 & 0.973 & 0.977 \\
\hline \multirow{3}{*}{$\begin{array}{l}\text { Elovich } \\
q_{t}=\frac{1}{\beta} \ln (t)+\frac{1}{\beta} \ln (\alpha \beta)\end{array}$} & \multirow{3}{*}{$q_{t}$ vs. $\ln t$} & $\beta\left(\mathrm{g} \mathrm{mg}^{-1}\right)$ & 0.019 & 0.013 & 0.011 & 0.008 & 0.008 \\
\hline & & $\alpha\left(\mathrm{mg} \mathrm{g}^{-1} \min ^{-1}\right)$ & 87.38 & 100.85 & 131.22 & 174.9 & 171.04 \\
\hline & & $\mathrm{R}^{2}$ & 0.984 & 0.985 & 0.978 & 0.984 & 0.982 \\
\hline \multicolumn{2}{|l|}{ Experimental data } & $\mathrm{q}_{\mathrm{e}(\exp )}\left(\mathrm{mg} \mathrm{g}^{-1}\right)$ & 185.91 & 245.42 & 310.86 & 397.31 & 400.51 \\
\hline
\end{tabular}

Table 5. Kinetic model parameters and correlation coefficients for adsorption of $\mathrm{MG}$ dye onto meso- $\mathrm{CaAl}_{2} \mathrm{O}_{4}$ (volume, $50 \mathrm{~mL}$; initial concentration, $50 \mathrm{mg} \mathrm{L}^{-1}$; adsorbent dose, $8 \mathrm{mg}$; solution temperature, $25^{\circ} \mathrm{C}$ ).

the pseudo-second-order model $\left(\mathrm{q}_{\mathrm{e}}\right.$, calc) and the experimental $\mathrm{qe}\left(\mathrm{q}_{\mathrm{e}}\right.$, exp) value are very close to each other, emphasizing the suitability of the pseudo-second-order model.

Thermodynamics of the adsorption. Van't Hoffs plot [ln $\left.\mathrm{K}_{\mathrm{C}} \mathrm{vs} 1 / \mathrm{T}(\mathrm{K})\right]$ was used to quantify thermodynamic parameters, such as Gibbs free energy change $\left(\Delta \mathrm{G}^{\circ}\right)$, entropy change $\left(\Delta \mathrm{S}^{\circ}\right)$, enthalpy change $\left(\Delta \mathrm{H}^{\circ}\right)$, and explain the thermodynamic behavior of $\mathrm{MG}$ dye adsorption onto meso- $\mathrm{CaAl}_{2} \mathrm{O}_{4}$. Thermodynamic parameters 


\begin{tabular}{|c|c|c|c|c|c|c|}
\hline \multirow{2}{*}{$\begin{array}{l}\text { MG concentration } \\
\mathbf{T}(\mathbf{k})\end{array}$} & \multicolumn{2}{|c|}{$25 \mathrm{mg} \mathrm{L}^{-1}$} & \multicolumn{2}{|c|}{$50 \mathrm{mg} \mathrm{L}^{-1}$} & \multicolumn{2}{|c|}{$100 \mathrm{mg} \mathrm{L}^{-1}$} \\
\hline & $\mathbf{k}_{\mathrm{C}}$ & $\Delta \mathrm{G}^{\circ}\left(\mathbf{k J} \mathrm{mol}^{-1}\right)$ & $\mathbf{k}_{\mathrm{C}}$ & $\Delta \mathrm{G}^{\circ}\left(\mathrm{kJ} \mathrm{mol}{ }^{-1}\right)$ & $\mathbf{k}_{\mathrm{C}}$ & $\Delta \mathbf{G}^{\circ}\left(\mathbf{k J ~ ~ m o l ^ { - 1 } )}\right.$ \\
\hline 278.15 & 8.185 & -4.86 & 5.337 & -3.87 & 0.887 & 0.28 \\
\hline 288.15 & 13.78 & -6.28 & 9.194 & -5.31 & 1.021 & -0.05 \\
\hline 298.15 & 34.89 & -8.80 & 28.03 & -8.26 & 1.319 & -0.69 \\
\hline 308.15 & 56.31 & -10.33 & 38.54 & -9.35 & 1.461 & -0.97 \\
\hline 318.15 & 100.3 & -12.19 & 80.08 & -11.59 & 1.607 & -1.25 \\
\hline 328.15 & 150.9 & -13.69 & 103.6 & -12.66 & 1.838 & -1.66 \\
\hline $\mathrm{R}^{2}$ & \multicolumn{2}{|l|}{0.992} & \multicolumn{2}{|l|}{0.978} & \multicolumn{2}{|l|}{0.983} \\
\hline$\Delta \mathrm{S}^{\circ}\left(\mathrm{J} \mathrm{mol}^{-1} \mathrm{k}^{-1}\right)$ & \multicolumn{2}{|l|}{181.55} & \multicolumn{2}{|l|}{183.6} & \multicolumn{2}{|l|}{39.05} \\
\hline$\Delta \mathrm{H}^{\circ}\left(\mathrm{kJ} \mathrm{mol}^{-1}\right)$ & \multicolumn{2}{|l|}{45.68} & \multicolumn{2}{|l|}{47.15} & \multicolumn{2}{|l|}{11.11} \\
\hline
\end{tabular}

Table 6. Thermodynamic parameters for the adsorption of $\mathrm{MG}$ dye onto meso- $\mathrm{CaAl}_{2} \mathrm{O}_{4}$ (volume $=50 \mathrm{~mL}$, adsorbent mass $=8 \mathrm{mg}$, contact time $=15 \mathrm{~min}$, and solution $\mathrm{pH} 8.0$ ).

of the MG dye adsorption onto meso- $\mathrm{CaAl}_{2} \mathrm{O}_{4}$ at different MG dye concentrations are presented in Table 6. As can be seen, the $\Delta \mathrm{G}^{\circ}$ values are in a negative range that implies the spontaneous $\mathrm{MG}$ dye adsorption onto meso- $\mathrm{CaAl}_{2} \mathrm{O}_{4}{ }^{71}$. Also, the $\Delta \mathrm{G}^{\circ}$ values decrease as the temperature rises, meaning that adsorption seems to be more desirable at higher temperatures. The obtained positive quantity of $\Delta \mathrm{H}^{\circ}\left(45.68,47.15\right.$, and $\left.11.11 \mathrm{~kJ} \mathrm{~mol}^{-1}\right)$ indicates that the process of MG dye adsorption is done endothermically ${ }^{72}$. In MG concentrations of 25 and $50 \mathrm{mg} \mathrm{L}^{-1}$, a significant interaction between the $\mathrm{MG}$ dye and meso- $\mathrm{CaAl}_{2} \mathrm{O}_{4}$ is also concluded by the high value of $\Delta \mathrm{H}^{\circ 73}$. However, decreasing the $\Delta \mathrm{H}^{\circ}$ at higher $\mathrm{MG}$ concentrations $\left(100 \mathrm{mg} \mathrm{L}^{-1}\right)$ indicates a decrease in the interactions between the meso- $\mathrm{CaAl}_{2} \mathrm{O}_{4}$ and the $\mathrm{MG}$ dye, which can be due to the quick saturation of active sites on the exterior surface of meso- $\mathrm{CaAl}_{2} \mathrm{O}_{4}$ at higher concentrations and prevents the accessing of more dye molecules to more unoccupied active sites. The values of $\Delta \mathrm{S}^{\circ}\left(181.55,183.6\right.$, and $39.05 \mathrm{~J} \mathrm{~mol}^{-1}$, ) are also positive, which suggests the increment of randomness at the interface of the meso- $\mathrm{CaAl}_{2} \mathrm{O}_{4}$ /solution during the process of MG dye adsorption ${ }^{74}$. This degree of randomness has decreased with decreases the mobility of molecules at higher MG concentrations $\left(100 \mathrm{mg} \mathrm{L}^{-1}\right)$.

Proposed adsorption mechanism. The MG dye molecules can be adsorbed onto meso- $\mathrm{CaAl}_{2} \mathrm{O}_{4}$ via different mechanisms such as electrostatic interactions, pore diffusion mechanism, hydrogen bonding, and chemical bonding. One of the important experimental data used for the investigation of adsorption mechanisms is those obtained from adsorption efficiency at various values of solution $\mathrm{pH}$. The solution $\mathrm{pH}$ affects the dissociation constant $\left(\mathrm{pK}_{\mathrm{a}}\right)$ of $\mathrm{MG}$ dye and the $\mathrm{pHpzc}$ of meso- $\mathrm{CaAl}_{2} \mathrm{O}_{4}$. As shown in Fig. $6 \mathrm{a}$, meso- $\mathrm{CaAl}_{2} \mathrm{O}_{4}$ has a positive or negative surface charge in different solution $\mathrm{pH}$ conditions. In addition, the dye molecules also have a cationic or anionic nature at different values of solution $\mathrm{pH}$. Therefore, under different solution $\mathrm{pH}$ conditions, the meso- $\mathrm{CaAl}_{2} \mathrm{O}$ and the $\mathrm{MG}$ dye molecules are different in electric charge and can interact through electrostatic interactions. The change in the percentage of adsorption under different solution $\mathrm{pH}$ conditions is evidence that electrostatic interactions has been one of the influential factors in adsorption. The presence of the pore diffusion mechanism is also possible owing to the high surface area and extremely porous nature of meso- $\mathrm{CaAl}_{2} \mathrm{O}_{4}$. As a result of pore diffusion or capillary condensation, the molecules of $\mathrm{MG}$ can be adsorbed by diffusing into the pores of meso- $\mathrm{CaAl}_{2} \mathrm{O}_{4}{ }^{75}$.

Furthermore, the probability of chemical bond participation in the adsorption process is illustrated by analyzing the surface functional groups of meso- $\mathrm{CaAl}_{2} \mathrm{O}_{4}$ before and after the $\mathrm{MG}$ dye adsorption. As shown in the FT-IR spectra (Fig. 9), after the MG dye adsorption onto meso-CaAl $\mathrm{O}_{4}$, several characteristic peaks of MG (indicated with different colors) are found in the meso- $\mathrm{CaAl}_{2} \mathrm{O}_{4}$ spectrum, which has not appeared in the spectrum of blank meso- $\mathrm{CaAl}_{2} \mathrm{O}_{4}$. This implies that adsorption probably also occurred through chemical bonds. This fact is also evident from the results of the adsorption kinetic assessment, in which the pseudo-second-order fitting model describes the process of MG adsorption. Further study of the FT-IR results reveals that the absorption peaks corresponding to oxygen-containing stretching vibrations on the meso- $\mathrm{CaAl}_{2} \mathrm{O}_{4}$ were shifted after $\mathrm{MG}$ adsorption, implying that the hydrogen bonding is formed between meso- $\mathrm{CaAl}_{2} \mathrm{O}_{4}$ and $\mathrm{MG}$ dye molecules during the adsorption process. Finally, $\mathrm{MG}$ adsorption by meso- $\mathrm{CaAl}_{2} \mathrm{O}_{4}$ was also confirmed by the UV-Vis spectroscopy results (Fig. 10a). It can be implied that the MG absorbance value decreases at $617 \mathrm{~nm}$ after the adsorption process. These results confirm the successful adsorption of $\mathrm{MG}$ onto meso- $\mathrm{CaAl}_{2} \mathrm{O}_{4}$. The photographic images of the MG solution before and after its adsorption onto the adsorbent are presented in Fig. 10a.

Application of the adsorbent for the treatment of industrial effluent. The MG dye adsorption investigation for real applications was performed at optimal conditions (adsorbent mass $=8 \mathrm{mg}$, contact time $=15 \mathrm{~min}$, initial MG dye concentration $=50 \mathrm{mg} \mathrm{L}^{-1}$, solution $\mathrm{pH}$ of 8.0 , and solution temperature of $25^{\circ} \mathrm{C}$ ). The mean percentage of MG removal from a real textile effluent is shown in Table 7 . According to the obtained values, the efficiency of the adsorbent for $\mathrm{MG}$ adsorption is $72.12 \% \pm 1.81$, which indicates the effectiveness of meso- $\mathrm{CaAl}_{2} \mathrm{O}_{4}$ for real applications. Also, the characteristics of the textile wastewater before and after treatment are given in Table 8 . 

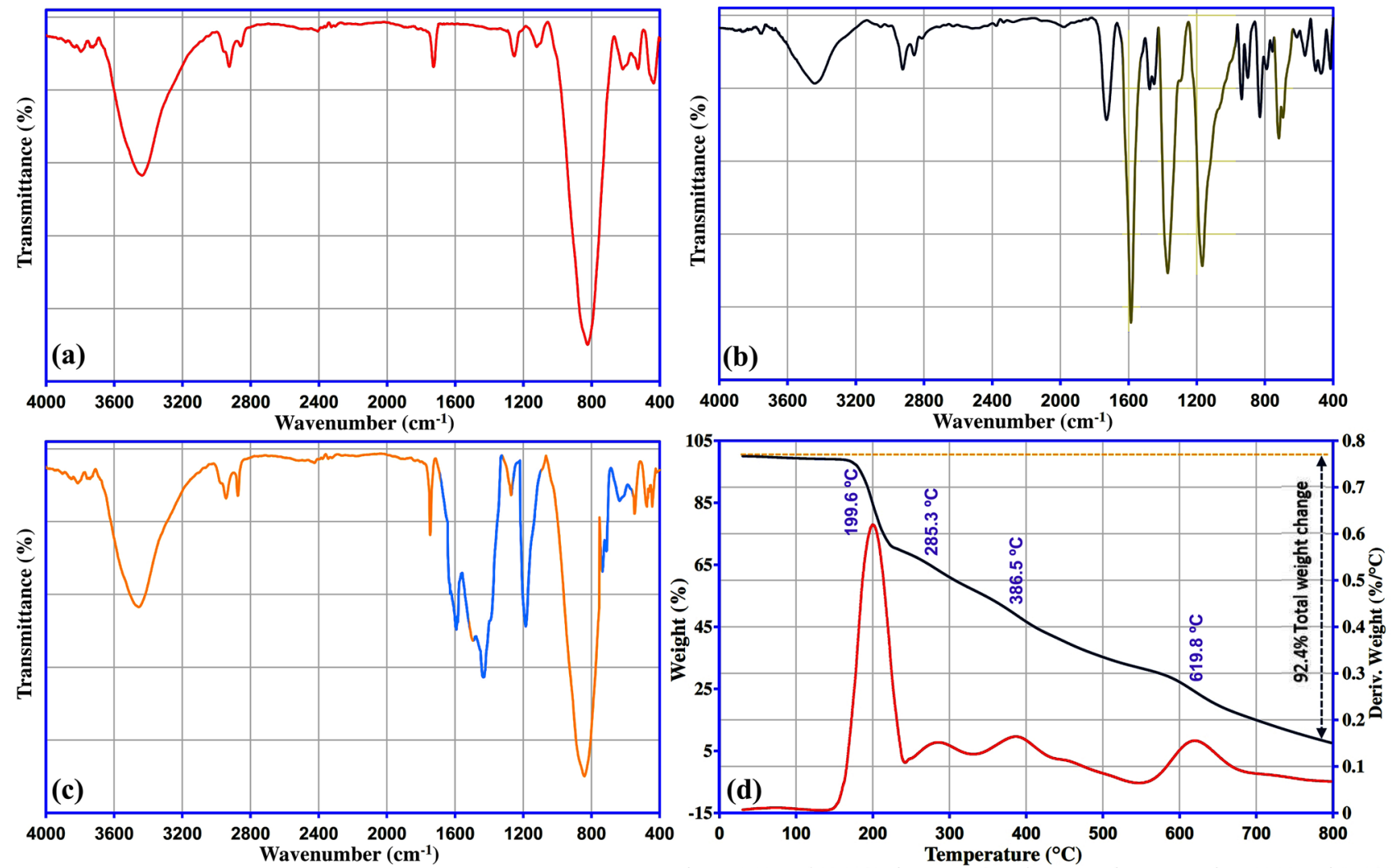

Figure 9. FT-IR spectra of (a) meso- $\mathrm{CaAl}_{2} \mathrm{O}_{4}$ before adsorption of $\mathrm{MG}$ dye, (b) $\mathrm{MG}$ dye, (c) meso-CaAl $\mathrm{O}_{4}$ after adsorption of MG dye, and (d) TGA/DTG curves of MG dye.

Microwave-assisted regeneration of the adsorbent. The regeneration of adsorbent is a critical factor for its application to be the effectiveness and economical. Owing to this reason, achieving a faster and easier regeneration method has always been considered. In this regard, the microwave-assisted regeneration of dyeloaded meso- $\mathrm{CaAl}_{2} \mathrm{O}_{4}$ was studied. Microwave power in the microwave heating method plays an essential role in the amount of temperature produced and can help regenerate the adsorbent. The changes in the temperature of meso- $\mathrm{CaAl}_{2} \mathrm{O}_{4}$ at different microwave powers $(300 \mathrm{~W}, 600 \mathrm{~W}$, and $900 \mathrm{~W})$ are shown in Fig. 10c. It is seen that an increase in temperature is obtained by a rise in the power of the microwave. In addition, the adsorption efficiencies of the regenerated meso- $\mathrm{CaAl}_{2} \mathrm{O}_{4}$ at various microwave powers are shown in Fig. 10b. The results express that the $\mathrm{R} \%$ of MG is greater with meso-CaAl $\mathrm{O}_{4}$ treated at higher microwave power. This can be due to the higher temperature produced at higher powers, which results in the higher degradation of MG from meso$\mathrm{CaAl}_{2} \mathrm{O}_{4}$.

In order to investigate and confirm MG degradation by microwave heating process, the TGA/DTG was applied. The results in Fig. $9 \mathrm{~d}$ show that degrading MG begins at the temperature of around $200{ }^{\circ} \mathrm{C}$, and at $800{ }^{\circ} \mathrm{C}$, it loses around $92.4 \%$ of its mass. However, the adsorbent shows a very high heat resistance, and it loses only $7.95 \%$ of its weight up to $800^{\circ} \mathrm{C}$, which is mostly corresponding to the moisture as mentioned before (Fig. $4 \mathrm{~d}$ ). Therefore, the results confirm a successful regeneration of meso- $\mathrm{CaAl}_{2} \mathrm{O}_{4}$ using the microwave-assisted heating method. Finally, the regeneration of the dye-loaded meso- $\mathrm{CaAl}_{2} \mathrm{O}_{4}$ was studied using the microwave-assisted heating method. For this purpose, an evaporating dish containing the saturated adsorbent was placed into the microwave and treated for $6 \mathrm{~min}$ at $900 \mathrm{~W}$. After the heating process, the treated meso- $\mathrm{CaAl}_{2} \mathrm{O}_{4}$ was washed three times with ultrapure water to thoroughly eliminate the carbon black and other materials left over from the MG degradation. The washed adsorbent was then placed in an oven at $110{ }^{\circ} \mathrm{C}$ to be dried for further use. The recyclability of meso- $\mathrm{CaAl}_{2} \mathrm{O}_{4}$ treated with microwave heating method is shown in Fig. 10d. As seen from the results, the adsorbent has a good reusability, so that after five reuses, the adsorption percentage of MG is still $>90 \%$, which indicates that the adsorbent is efficient and economical.

\section{Conclusions}

A citric acid-assisted sol-gel auto-combustion process was used to successfully synthesize meso- $\mathrm{CaAl}_{2} \mathrm{O}_{4}$ as an adsorbent, which was then utilized for efficient removal of MG, a cationic dye, from synthetic/real effluent. The synthesized adsorbent was characterized using different techniques. The values obtained for specific surface area, $\mathrm{BJH}$ pore diameter, and total pore volume of meso- $\mathrm{CaAl}_{2} \mathrm{O}_{4}$ were $148.46 \mathrm{~m}^{2} \mathrm{~g}^{-1}, 19 \mathrm{~nm}$, and $1.39 \mathrm{~cm}^{3} \mathrm{~g}^{-1}$, respectively. The adsorption optimal conditions, solution $\mathrm{pH}\left(\mathrm{X}_{1}\right)=8.0$, MG concentration $\left(\mathrm{X}_{2}\right)=50 \mathrm{mg} \mathrm{L}^{-1}$, 

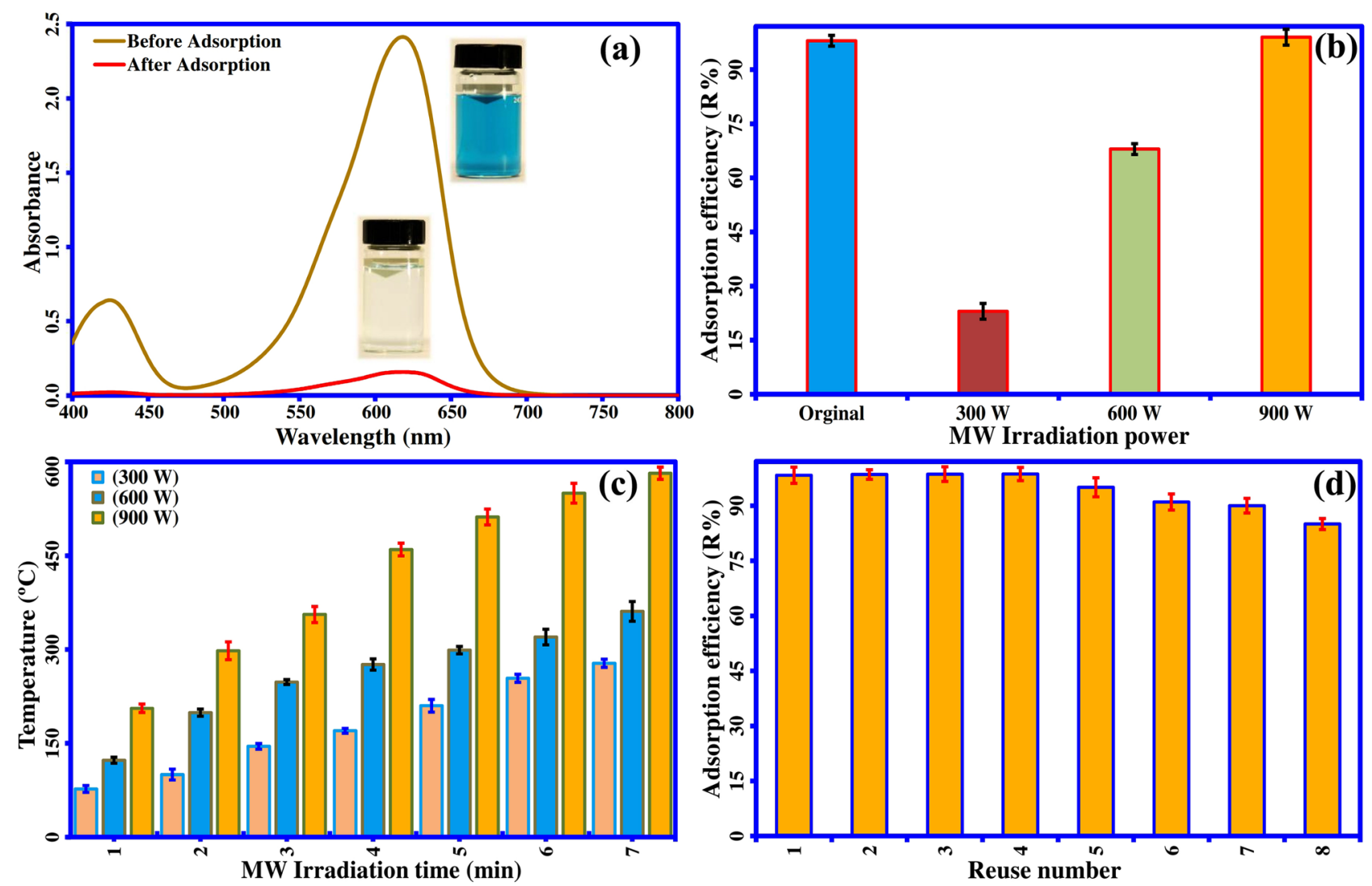

Figure 10. (a) $\mathrm{UV}-\mathrm{Vis}$ spectra of $\mathrm{MG}$ dye solution before and after adsorption (adsorbent mass $=8 \mathrm{mg}$, $\mathrm{V}=50 \mathrm{~mL}, \mathrm{~T}=25^{\circ} \mathrm{C}, \mathrm{pH} 8.0$, and contact time $\left.=15 \mathrm{~min}\right),(\mathbf{b})$ the $\mathrm{R} \%$ of regenerated adsorbent irradiated at various MW powers, (c) the temperature profiles of the sample measured by the thermocouple at different MW powers, and (d) the $\mathrm{R} \%$ of $\mathrm{MG}$ dye onto meso- $\mathrm{CaAl}_{2} \mathrm{O}_{4}$ at different cycles (error bars presents \pm standard deviations, $\mathrm{n}=3$ ).

\begin{tabular}{|l|l|l|}
\hline Number & Within-day (repeatability) & Between-day (reproducibility) \\
\hline 1 & 70.85 & 70.56 \\
\hline 2 & 73.24 & 71.23 \\
\hline 3 & 71.90 & 73.45 \\
\hline 4 & 75.80 & 71.76 \\
\hline 5 & 69.45 & 72.97 \\
\hline Mean \pm SD & $72.12 \pm 1.81$ & \\
\hline
\end{tabular}

Table 7. Data of the precision for the adsorption of $\mathrm{MG}$ dye onto meso- $\mathrm{CaAl}_{2} \mathrm{O}_{4}$ in the textile wastewater (volume $=50 \mathrm{~mL}$, initial dye concentration $=50 \mathrm{mg} \mathrm{L}^{-1}$, adsorbent mass $=15 \mathrm{mg}$, contact time $=15 \mathrm{~min}$, $\left.\mathrm{T}=25^{\circ} \mathrm{C}, \mathrm{pH} 8.0\right)$.

meso-CaAl $\mathrm{O}_{4}$ mass $\left(\mathrm{X}_{3}\right)=8 \mathrm{mg}$, contact time $\left(\mathrm{X}_{4}\right)=15 \mathrm{~min}$ and solution temperature $\left(\mathrm{X}_{5}\right)=25^{\circ} \mathrm{C}$, was obtained based on RSM-CCD. Langmuir isotherm fitting model well explained the equilibrium adsorption of MG onto the adsorbent, presenting $587.5 \mathrm{mg} \mathrm{g}^{-1}$ as the maximum monolayer adsorption capacity. Pseudo-second-order kinetic model carried out very well the fitting of the experimental kinetic data. Furthermore, the attained values of thermodynamic parameters (positive values of $\Delta \mathrm{H}^{\circ}$ and $\Delta \mathrm{S}^{\circ}$, and negative values of $\Delta \mathrm{G}^{\circ}$ ) showed the adsorption process of $\mathrm{MG}$ dye to be endothermic and spontaneous, and suggested the increment of randomness at the interface of the meso- $\mathrm{CaAl}_{2} \mathrm{O}_{4} /$ solution during the process of $\mathrm{MG}$ adsorption. The dye-loaded meso- $\mathrm{CaAl}_{2} \mathrm{O}_{4}$ was successfully regenerated by the microwave-assisted heating method, and the adsorption percentage of $\mathrm{MG}$ dye was still $>90 \%$ after five reuses. In conclusion, the meso-CaAl $\mathrm{O}_{4}$ can be suggested for the efficient removal of hazardous dyes, especially MG dye, from wastewaters. 


\begin{tabular}{|c|c|c|c|c|}
\hline \multirow[b]{2}{*}{ Characteristic } & \multirow[b]{2}{*}{ Unit } & \multicolumn{2}{|c|}{ Treatment } & \multirow[b]{2}{*}{ Reduction \% } \\
\hline & & Before & After & \\
\hline Temperature & $\mathrm{C}$ & 26.8 & 27.1 & - \\
\hline Conductivity & $\mu \mathrm{S} \mathrm{cm}^{-1}$ & 2985 & 869 & 70.9 \\
\hline Total dissolved solids (TDS) & $\mathrm{mg} \mathrm{L}^{-1}$ & 1910 & 493 & 74.2 \\
\hline Chemical oxygen demand (COD) & $\mathrm{mg} \mathrm{L}^{-1}$ & 1262 & 130 & 89.7 \\
\hline Biochemical oxygen demand $\left(\mathrm{BOD}_{5}\right)$ & $\mathrm{mg} \mathrm{L}^{-1}$ & 336 & 41 & 87.8 \\
\hline Total suspended solids (TSS) & $\mathrm{mg} \mathrm{L}^{-1}$ & 349 & 92 & 73.6 \\
\hline Color & $\mathrm{Pt}-\mathrm{Co}$ & 1360 & 51 & 96.2 \\
\hline Turbidity & NTU & 136 & 3.3 & 97.6 \\
\hline $\mathrm{pH}$ & - & 8.1 & 7.9 & - \\
\hline
\end{tabular}

Table 8. Characterization of the textile wastewater before and after treatment.

Received: 22 May 2021; Accepted: 27 October 2021

Published online: 23 November 2021

\section{References}

1. Kebede, W. L., Kuo, D.-H., Bekena, F. T. \& Duresa, L. W. Highly efficient In-Mo(O, S)2 oxy-sulfide for degradation of organic pollutants under visible light irradiation: An example of photocatalyst on its dye selectivity. Chemosphere 254, 126823 (2020).

2. Roosta, M., Ghaedi, M. \& Asfaram, A. Simultaneous ultrasonic-assisted removal of malachite green and safranin O by copper nanowires loaded on activated carbon: Central composite design optimization. RSC Adv. 5, 57021-57029 (2015).

3. Wang, S. et al. Occurrence and transformation of phosphonates in textile dyeing wastewater along full-scale combined treatment processes. Water Res. 184, 116173 (2020).

4. Asfaram, A., Ghaedi, M., Ahmadi Azqhandi, M. H., Goudarzi, A. \& Hajati, S. Ultrasound-assisted binary adsorption of dyes onto Mn@CuS/ZnS-NC-AC as a novel adsorbent: Application of chemometrics for optimization and modeling. J. Ind. Eng. Chem. 54, 377-388 (2017).

5. Abd Rani, U. et al. Sustainable production of nitrogen-doped carbon quantum dots for photocatalytic degradation of methylene blue and malachite green. J. Water Process Eng. 40, 101816 (2020).

6. Teymori, M., Khorsandi, H., Aghapour, A. A., Jafari, S. J. \& Maleki, R. Electro-Fenton method for the removal of Malachite Green: Effect of operational parameters. Appl. Water Sci. 10, 1-14 (2020).

7. Ali, F. et al. Sorptive removal of malachite green dye by activated charcoal: process optimization, kinetic, and thermodynamic evaluation. Case Stud. Chem. Environ. Eng. 1, 100025 (2020).

8. Zhang, Q., Lin, Q., Zhang, X. \& Chen, Y. A novel hierarchical stiff carbon foam with graphene-like nanosheet surface as the desired adsorbent for malachite green removal from wastewater. Environ. Res. 179, 108746 (2019).

9. Ahmad, M. A., Eusoff, M. A., Oladoye, P. O., Adegoke, K. A. \& Bello, O. S. Statistical optimization of Remazol Brilliant Blue R dye adsorption onto activated carbon prepared from pomegranate fruit peel. Chem. Data Collect. 28, 100426 (2020).

10. Zhang, F., Chen, X., Wu, F. \& Ji, Y. High adsorption capability and selectivity of ZnO nanoparticles for dye removal. Colloid. Surf. A 509, 474-483 (2016).

11. Gupta, K. \& Khatri, O. P. Reduced graphene oxide as an effective adsorbent for removal of malachite green dye: Plausible adsorption pathways. J. Colloid Interface Sci. 501, 11-21 (2017).

12. Arabkhani, P., Asfaram, A. \& Ateia, M. Easy-to-prepare graphene oxide/sodium montmorillonite polymer nanocomposite with enhanced adsorption performance. J. Water Process Eng. 38, 101651 (2020).

13. Arabkhani, P. \& Asfaram, A. Development of a novel three-dimensional magnetic polymer aerogel as an efficient adsorbent for malachite green removal. J. Hazard. Mater. 384, 121394 (2020).

14. Méndez, A., Fernández, F. \& Gascó, G. Removal of malachite green using carbon-based adsorbents. Desalination 206, 147-153 (2007).

15. Lin, K.-Y.A. \& Chang, H.-A. Ultra-high adsorption capacity of zeolitic imidazole framework-67 (ZIF-67) for removal of malachite green from water. Chemosphere 139, 624-631 (2015).

16. Pant, K. K. \& Kunzru, D. Catalytic pyrolysis of n-heptane on unpromoted and potassium promoted calcium aluminates. Chem. Eng. J. 87, 219-225 (2002).

17. Trofymluk, O., Toda, Y., Hosono, H. \& Navrotsky, A. Energetics of formation and oxidation of microporous calcium aluminates: A new class of electrides and ionic conductors. Chem. Mater. 17, 5574-5579 (2005).

18. Wang, F. et al. Superhydrophobic calcium aluminate cement with super mechanical stability. Ind. Eng. Chem. Res. 58, 10373-10382 (2019).

19. Parreira, R. M., Andrade, T. L., Luz, A. P., Pandolfelli, V. C. \& Oliveira, I. R. Calcium aluminate cement-based compositions for biomaterial applications. Ceram. Int. 42, 11732-11738 (2016).

20. Acuña-Gutiérrez, I. O. et al. Development of LiCl-containing calcium aluminate cement for bone repair and remodeling applications. Mater. Sci. Eng. C 70, 357-363 (2017).

21. Oh, S.-H., Choi, S.-Y., Lee, Y.-K. \& Kim, K. N. Preparation of calcium aluminate cement for hard tissue repair: Effects of lithium fluoride and maleic acid on setting behavior, compressive strength, and biocompatibility. J. Biomed. Mater. Res. 62, 593-599 (2002).

22. Nayebzadeh, H., Saghatoleslami, N. \& Tabasizadeh, M. Optimization of the activity of KOH/calcium aluminate nanocatalyst for biodiesel production using response surface methodology. J. Taiwan Inst. Chem. Eng. 68, 379-386 (2016).

23. Jiang, Y. et al. Aqueous Cr (VI) removal by Friedel's salt adsorbent prepared from calcium aluminate-rich cementitious materials. Environ. Technol. 36, 2086-2093 (2015).

24. Mercury, J. R., De Aza, A. \& Pena, P. Synthesis of $\mathrm{CaAl}_{2} \mathrm{O}_{4}$ from powders: Particle size effect. J. Eur. Ceram. Soc. 25, 3269-3279 (2005).

25. Kurajica, S., Mali, G., Gazivoda, T., Sipusic, J. \& Mandic, V. A spectroscopic study of calcium aluminate gels obtained from aluminium sec-butoxide chelated with ethyl acetoacetate in various ratios. J. Sol-Gel Sci. Technol. 50, 58-68 (2009).

26. Gaki, A., Perraki, T. \& Kakali, G. Wet chemical synthesis of monocalcium aluminate. J. Eur. Ceram. Soc. 27, 1785-1789 (2007).

27. Rodríguez, M., Aguilar, C. \& Aghayan, M. Solution combustion synthesis and sintering behavior of $\mathrm{CaAl}_{2} \mathrm{O}_{4}$. Ceram. Int. 38, 395-399 (2012). 
28. Han, C.-H., Han, S.-D., Gwak, J. \& Khatkar, S. Synthesis of indium tin oxide (ITO) and fluorine-doped tin oxide (FTO) nanopowder by sol-gel combustion hybrid method. Mater. Lett. 61, 1701-1703 (2007).

29. Wang, K. et al. Polydopamine-coated magnetic nanochains as efficient dye adsorbent with good recyclability and magnetic separability. J. Colloid Interface Sci. 516, 263-273 (2018).

30. Arabkhani, P., Javadian, H., Asfaram, A. \& Ateia, M. Decorating graphene oxide with zeolitic imidazolate framework (ZIF-8) and pseudo-boehmite offers ultra-high adsorption capacity of diclofenac in hospital effluents. Chemosphere 271, 129610 (2021).

31. Karri, R. R., Tanzifi, M., Yaraki, M. T. \& Sahu, J. Optimization and modeling of methyl orange adsorption onto polyaniline nanoadsorbent through response surface methodology and differential evolution embedded neural network. J. Environ. Manag. 223, 517-529 (2018).

32. Omorogie, M. O., Babalola, J. O. \& Unuabonah, E. I. Regeneration strategies for spent solid matrices used in adsorption of organic pollutants from surface water: A critical review. Desalin. Water Treat. 57, 518-544 (2016).

33. Bazrafshan, A. A., Ghaedi, M., Hajati, S., Naghiha, R. \& Asfaram, A. Synthesis of ZnO-nanorod-based materials for antibacterial, antifungal activities, DNA cleavage and efficient ultrasound-assisted dyes adsorption. Ecotoxicol. Environ. Saf. 142, 330-337 (2017).

34. Asfaram, A., Ghaedi, M., Yousefi, F. \& Dastkhoon, M. Experimental design and modeling of ultrasound assisted simultaneous adsorption of cationic dyes onto ZnS: Mn-NPs-AC from binary mixture. Ultrason. Sonochem. 33, 77-89 (2016).

35. Ranjbar, A. \& Rezaei, M. Low temperature synthesis of nanocrystalline calcium aluminate compounds with surfactant-assisted precipitation method. Adv. Powder Technol. 25, 467-471 (2014).

36. Verbraeken, M. C. \& Brandani, S. A priori predictions of type I and type V isotherms by the rigid adsorbent lattice fluid. Adsorption 26, 989-1000 (2019)

37. McCusker, L., Liebau, F. \& Engelhardt, G. Nomenclature of structural and compositional characteristics of ordered microporous and mesoporous materials with inorganic hosts (IUPAC recommendations 2001). Pure. Appl. Chem. 73, 381-394 (2001).

38. Asfaram, A. et al. Synthesis of $\mathrm{Fe}_{3} \mathrm{O}_{4} @ \mathrm{CuS} @ \mathrm{Ni}_{2} \mathrm{P}-\mathrm{CNTs}$ magnetic nanocomposite for sonochemical-assisted sorption and preconcentration of trace Allura Red from aqueous samples prior to HPLC-UV detection: CCD-RSM design. Ultrason. Sonochem. 44, 240-250 (2018).

39. Mourabet, M. et al. Removal of fluoride from aqueous solution by adsorption on hydroxyapatite (HAp) using response surface methodology. J. Saudi Chem. Soc. 19, 603-615 (2015).

40. Alipanahpour Dil, E., Ghaedi, M., Asfaram, A., Mehrabi, F. \& Sadeghfar, F. Efficient adsorption of Azure B onto CNTs/Zn:ZnO@ $\mathrm{Ni}_{2} \mathrm{P}-\mathrm{NCs}$ from aqueous solution in the presence of ultrasound wave based on multivariate optimization. J. Ind. Eng. Chem. 74, 55-62 (2019).

41. Sharifpour, E., Alipanahpour Dil, E., Asfaram, A., Ghaedi, M. \& Goudarzi, A. Optimizing adsorptive removal of malachite green and methyl orange dyes from simulated wastewater by $\mathrm{Mn}$-doped $\mathrm{CuO}$-Nanoparticles loaded on activated carbon using CCDRSM: Mechanism, regeneration, isotherm, kinetic, and thermodynamic studies. Appl. Organomet. Chem. 33, 1-10 (2019).

42. Mahmoodi, N. M., Oveisi, M., Taghizadeh, A. \& Taghizadeh, M. Novel magnetic amine functionalized carbon nanotube/metalorganic framework nanocomposites: From green ultrasound-assisted synthesis to detailed selective pollutant removal modelling from binary systems. J. Hazard. Mater. 368, 746-759 (2019).

43. Senol, Z. M., Gürsoy, N., Simșek, S., Özer, A. \& Karakus, N. Removal of food dyes from aqueous solution by chitosan-vermiculite beads. Int. J. Biol. Macromol. 148, 635-646 (2020).

44. Elwakeel, K. Z., El-Bindary, A. A., El-Sonbati, A. Z. \& Hawas, A. R. Adsorption of toxic acidic dye from aqueous solution onto diethylenetriamine functionalized magnetic glycidyl methacrylate-N, N[prime or minute]-methylenebisacrylamide. RSC Adv. 6, 3350-3361 (2016).

45. Chen, L. et al. Facile synthesis of mesoporous carbon nanocomposites from natural biomass for efficient dye adsorption and selective heavy metal removal. RSC Adv. 6, 2259-2269 (2016).

46. Liu, H., Chen, L. \& Ding, J. Adsorption behavior of magnetic amino-functionalized metal-organic framework for cationic and anionic dyes from aqueous solution. RSC Adv. 6, 48884-48895 (2016)

47. Du, Q. et al. A graphene-melamine-sponge for efficient and recyclable dye adsorption. RSC Adv. 6, 54589-54596 (2016).

48. Mohammadi, A., Daemi, H. \& Barikani, M. Fast removal of malachite green dye using novel superparamagnetic sodium alginatecoated $\mathrm{Fe}_{3} \mathrm{O}_{4}$ nanoparticles. Int. J. Biolog. Macromol. 69, 447-455 (2014).

49. Zhang, X. et al. Graphene oxide caged in cellulose microbeads for removal of malachite green dye from aqueous solution. J. Colloid Interface Sci. 437, 277-282 (2015).

50. Fil, B. A. Isotherm, kinetic, and thermodynamic studies on the adsorption behavior of malachite green dye onto montmorillonite clay. Part. Sci. Technol. 34, 118-126 (2016).

51. Hosseinzadeh, H. \& Ramin, S. Fabrication of starch-graft-poly(acrylamide)/graphene oxide/hydroxyapatite nanocomposite hydrogel adsorbent for removal of malachite green dye from aqueous solution. Int. J. Biol. Macromol. 106, 101-115 (2018).

52. Zhang, J. et al. Studies of malachite green adsorption on covalently functionalized $\mathrm{Fe}_{3} \mathrm{O}_{4} @ \mathrm{SiO}_{2}$-graphene oxides core-shell magnetic microspheres. J. Sol-Gel Sci. Technol. 82, 424-431 (2017).

53. Liu, A., Zhou, W., Shen, K., Liu, J. \& Zhang, X. One-pot hydrothermal synthesis of hematite-reduced graphene oxide composites for efficient removal of malachite green from aqueous solution. RSC Adv. 5, 17336-17342 (2015).

54. Soni, A., Tiwari, A. \& Bajpai, A. K. Removal of malachite green from aqueous solution using nano-iron oxide-loaded alginate microspheres: batch and column studies. Res. Chem. Intermed. 40, 913-930 (2014).

55. Shamsizadeh, A., Ghaedi, M., Ansari, A., Azizian, S. \& Purkait, M. K. Tin oxide nanoparticle loaded on activated carbon as new adsorbent for efficient removal of malachite green-oxalate: Non-linear kinetics and isotherm study. J. Mol. Liq. 195, 212-218 (2014).

56. Roosta, M. et al. Optimization of the combined ultrasonic assisted/adsorption method for the removal of malachite green by gold nanoparticles loaded on activated carbon: Experimental design. Spectrochim. Acta A 118, 55-65 (2014).

57. Prasad, K., Prajapati, S. \& Selvaraj, K. Efficient sorption and photocatalytic degradation of malachite green dye onto NiS nanoparticles prepared using novel green approach. Korean J. Chem. Eng. 32, 1986-1992 (2015).

58. Abou-Gamra, Z. M. \& Ahmed, M. A. TiO 2 nanoparticles for removal of malachite green dye from waste water. Adv. Chem. Eng. Sci. 5, 373-388 (2015).

59. Ai, L., Huang, H., Chen, Z., Wei, X. \& Jiang, J. Activated carbon/CoFe $\mathrm{O}_{4}$ composites: Facile synthesis, magnetic performance and their potential application for the removal of malachite green from water. Chem. Eng. J. 156, 243-249 (2010).

60. Robati, D. et al. Kinetics and thermodynamics of malachite green dye adsorption from aqueous solutions on graphene oxide and reduced graphene oxide. J. Mol. Liq. 214, 259-263 (2016).

61. Abdelrahman, E. A. Synthesis of zeolite nanostructures from waste aluminum cans for efficient removal of malachite green dye from aqueous media. J. Mol. Liq. 253, 72-82 (2018).

62. Yin, G., Sun, Z., Gao, Y. \& Xu, S. Preparation of expanded graphite for malachite green dye removal from aqueous solution. Microchem. J. 166, 106190 (2021).

63. Sykam, N., Jayram, N. D. \& Rao, G. M. Highly efficient removal of toxic organic dyes, chemical solvents and oils by mesoporous exfoliated graphite: Synthesis and mechanism. J. Water Process. Eng. 25, 128-137 (2018).

64. Guo, X. et al. Removal of basic dyes (malachite green) from aqueous medium by adsorption onto amino functionalized graphenes in batch mode. Desalin. Water Treat. 53, 818-825 (2015).

65. Nethaji, S., Sivasamy, A., Thennarasu, G. \& Saravanan, S. Adsorption of Malachite Green dye onto activated carbon derived from Borassus aethiopum flower biomass. J. Hazard. Mater. 181, 271-280 (2010). 
66. Shirmardi, M. et al. The adsorption of malachite green (MG) as a cationic dye onto functionalized multi walled carbon nanotubes. Korean J. Chem. Eng. 30, 1603-1608 (2013).

67. Bulut, E., Özacar, M. \& Şengil, İA. Adsorption of malachite green onto bentonite: Equilibrium and kinetic studies and process design. Micropor. Mesopor. Mat. 115, 234-246 (2008).

68. Arellano-Cárdenas, S., López-Cortez, S., Cornejo-Mazón, M. \& Mares-Gutiérrez, J. C. Study of malachite green adsorption by organically modified clay using a batch method. Appl. Surf. Sci. 280, 74-78 (2013).

69. Wang, S. \& Ariyanto, E. Competitive adsorption of malachite green and $\mathrm{Pb}$ ions on natural zeolite. J. Colloid Interface Sci. 314, 25-31 (2007).

70. Boukhalfa, N., Boutahala, M., Djebri, N. \& Idris, A. Kinetics, thermodynamics, equilibrium isotherms, and reusability studies of cationic dye adsorption by magnetic alginate/oxidized multiwalled carbon nanotubes composites. Int. J. Biol. Macromol. 123, 539-548 (2019).

71. Saleh, T. A., Tuzen, M. \& Sar1, A. Magnetic vermiculite-modified by poly(trimesoyl chloride-melamine) as a sorbent for enhanced removal of bisphenol A. J. Environ. Chem. Eng. 7, 103436 (2019).

72. Munagapati, V. S. \& Kim, D. S. Equilibrium isotherms, kinetics, and thermodynamics studies for congo red adsorption using calcium alginate beads impregnated with nano-goethite. Ecotoxicol. Environ. Safety 141, 226-234 (2017).

73. Zhu, Y. et al. Removal of methylene blue from aqueous solution by cattle manure-derived low temperature biochar. RSC Adv. 8 , 19917-19929 (2018).

74. Hiew, B. Y. Z. et al. Adsorptive removal of diclofenac by graphene oxide: Optimization, equilibrium, kinetic and thermodynamic studies. J. Taiwan Inst. Chem. Eng. 98, 150-162 (2019).

75. Mittal, H., Morajkar, P. P., Al Alili, A. \& Alhassan, S. M. In-situ synthesis of $\mathrm{ZnO}$ nanoparticles using gum arabic based hydrogels as a self-template for effective malachite green dye adsorption. J. Polym. Environ. 28, 1637-1653 (2020).

\section{Author contributions}

P.A.: Methodology, Investigation, Writing—original draft, Validation, Data Curation, Writing_review \& editing. A.A. Conceptualization, Project administration, Data curation, Methodology, Software, Formal analysis, Writing—original draft, Writing_review \& editing,S.N.H. Investigation, Methodology, Software. H.J. Methodology, Investigation, Data Curation, Writing-review \& editing. All authors discussed the results and contributed to the final manuscript.

\section{Competing interests}

The authors declare no competing interests.

\section{Additional information}

Supplementary Information The online version contains supplementary material available at https:/doi.org/ 10.1038/s41598-021-02213-2.

Correspondence and requests for materials should be addressed to A.A.

Reprints and permissions information is available at www.nature.com/reprints.

Publisher's note Springer Nature remains neutral with regard to jurisdictional claims in published maps and institutional affiliations.

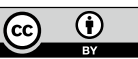

Open Access This article is licensed under a Creative Commons Attribution 4.0 International License, which permits use, sharing, adaptation, distribution and reproduction in any medium or format, as long as you give appropriate credit to the original author(s) and the source, provide a link to the Creative Commons licence, and indicate if changes were made. The images or other third party material in this article are included in the article's Creative Commons licence, unless indicated otherwise in a credit line to the material. If material is not included in the article's Creative Commons licence and your intended use is not permitted by statutory regulation or exceeds the permitted use, you will need to obtain permission directly from the copyright holder. To view a copy of this licence, visit http://creativecommons.org/licenses/by/4.0/.

(C) The Author(s) 2021 